Cornell Law Library

Scholarship@Cornell Law: A Digital Repository

Cornell Law Faculty Publications

Faculty Scholarship

$12-1-2003$

\title{
Shareholder as Ulysses: Some Empirical Evidence on Why Investors in Public Corporations Tolerate Board Governance
}

Lynn A. Stout

Cornell Law School,1s483@cornell.edu

Follow this and additional works at: http://scholarship.law.cornell.edu/facpub

Part of the Business Law, Public Responsibility, and Ethics Commons, and the Corporation and Enterprise Law Commons

\section{Recommended Citation}

Stout, Lynn A., "Shareholder as Ulysses: Some Empirical Evidence on Why Investors in Public Corporations Tolerate Board Governance" (2003). Cornell Law Faculty Publications. Paper 451.

http://scholarship.law.cornell.edu/facpub/451

This Article is brought to you for free and open access by the Faculty Scholarship at Scholarship@Cornell Law: A Digital Repository. It has been accepted for inclusion in Cornell Law Faculty Publications by an authorized administrator of Scholarship@Cornell Law: A Digital Repository. For more information, please contact jmp8@cornell.edu. 


\title{
INVESTORS’ CHOICES
}

\section{THE SHAREHOLDER AS ULYSSES: SOME EMPIRICAL EVIDENCE ON WHY INVESTORS IN PUBLIC CORPORATIONS TOLERATE BOARD GOVERNANCE}

\author{
LYNN A. STOUT
}

\begin{abstract}
This Article evaluates two possible explanations for why shareholders of public corporations tolerate board control of corporate assets and outputs: the widely accepted monitoring hypothesis, which posits that shareholders rely on boards primarily to control the "agency costs" associated with turning day-to-day control over the firm over to self-interested corporate executives, and the mediating hypothesis, which posits that shareholders also seek to "tie their own hands" by ceding control to directors as a means of attracting the extracontractual, firmspecific investments of such stakeholder groups as executives, creditors, and rankand-file employees.

Part I reviews each hypothesis and concludes that each is theoretically plausible and internally consistent, and that the validity of each theory must be established or rejected on the basis of empirical evidence. Part II evaluates the available empirical evidence, including new evidence on charter provisions of initial public offerings, and concludes that, as both a positive and a normative matter, corporate takeover law is consistent with the view that directors are not just monitors, but also perform a mediating function. Finally, Part III discusses future directions for empirical research, identifies some pitfalls to be avoided, and concludes that the current empirical evidence favors the mediating model.
\end{abstract}

\section{INTRODUCTION}

Shareholders are often described as the "owners" of corporations. Since at least the days of Adolph Berle and Gardiner Means, however,

${ }^{\dagger}$ Professor of Law, University of California at Los Angeles School of Law; Principal Investigator, UCL.A-Sloan Foundation Research Program on Business Organizations. I would like to thank Bill Allen, Iman Anabtawi, Stephen Bainbridge, Steve Banks, Lucian Bebchuk, Margaret Blair, John Coates, Lynne Dallas, Mike Klausner, Bill Klein, Lynn LoPucki, Douglas Olin, and the Honorable Leo Strine for their insights in discussions on this topic and comments on earlier drafts.

${ }^{1}$ See, e.g., Malone v. Brincat, 722 A.2d 5, 9 (Del. 1998) (stating that " $[\mathrm{t}]$ he board of directors has the legal responsibility to manage the business of a corporation for the benefit of its shareholder owners"); LEWIS D. SOLOMON ET AL., CORPORATIONS: LAW AND POLICY 348 (4th ed. 1998) (asserting that "shareholders are considered to be the corporation's ultimate owners"). Nevertheless, as a number of scholars have noted, 
corporate scholars have understood that in public corporations, shareholder "ownership" does not mean shareholder control. ${ }^{2}$ To the contrary, in the typical large public firm with dispersed stock ownership, control over the corporation's assets and outputs rests in theory and in practice not with stockholders, but with the company's board of directors.

This delegation of control poses a puzzle for corporate theorists. The investor who uses her hard-earned money to buy shares from a public firm relinquishes her power to determine how those funds will be used in the future. Her personal assets become corporate assets subject to the directors' control. It is now the directors, and not the investor, who will decide how the firm shall be run, whom it shall hire, and in what it shall invest. It is also now the directors, and not the investor, who will decide whether corporate earnings will be used to pay dividends-or used instead to build empires, raise salaries, and support charities. ${ }^{3}$

the metaphor of shareholder ownership is both inaccurate and misleading. See, e.g., Stephen M. Bainbridge, The Board of Directors as a Nexus of Contracts, 88 IOWA L. REV. 1, 3 n.5 (2002) (claiming that "ownership is not a particularly useful concept in the corporate context"); Margaret M. Blair, Corporate "Otonership," BROOKINGS REv., Winter 1995, at 16, 16-17 (arguing that labeling shareholders as "owners" incorrectly implies that shareholders possess certain rights generally associated with ownership); Margaret M. Blair \& Lynn A. Stout, Director Accountability and the Mediating Role of the Corporate Board, 79 WASH. U. L.Q. 403, 412-13 (2001) ("Options theory destroys any notion that shareholders can be uniquely described, in economic terms at least, as 'owners' of corporations."); G. Mitu Gulati et al., Connected Contracts, 47 UCLA L. REv. 887, 893 (2000) (describing the models in which shareholders are deemed owners or principals as "incomplete"); Lynn A. Stout, Bad and Not-So-Bad Arguments for Shareholder Primacy, 75 S. CAL. L. REV. 1189, 1192 (2002) ("From both a legal and economic perspective, the claim that shareholders own the corporation ... simply is empirically incorrect.").

${ }^{2}$ The observation that stock ownership is generally divorced from control in public firms is often associated with ADOLPH A. BERLE \& GARDINER C. MEANS, THE MODERN CORPORATION AND PRIVATE PROPERTY (photo. reprint 1982) (1932).

${ }^{3}$ See generally Margaret M. Blair \& Lynn A. Stout, A Team Production Theory of Corporate Law, 85 VA. L. REV. 247, 290-315 (1999). In extreme cases, shareholders of a public firm might overcome the hurdles to collective action described by Berle and Means and remove an incumbent board by means of a proxy fight. A board can also lose control of a firm if a hostile bidder appears, surmounts the battery of antitakeover defenses that typically surround a modern company, and ousts the directors. Yet both proxy contests and hostile bids are rare and expensive. As a result, the directors of most public firms as a practical matter enjoy a wide range of latitude to use corporate assets and distribute corporate earnings in a fashion that does not help-and may even harm-the firm's shareholders. See infra text accompanying notes 52-58 (discussing director discretion). See generally Stout, supra note 1, at 1192-95 (describing how directors enjoy legal discretion to divert firm assets and earnings to nonshareholder groups and how shareholders' voting and sale rights provide only limited constraints on this discretion). 
The end result is a system of public corporate governance that has been aptly described as "director primacy" instead of "shareholder primacy." This raises the question: why do shareholders tolerate such an arrangement? On first inspection, one might conclude that shareholders accept director primacy in public firms simply because corporate law requires it. Section 141(a) of the Delaware Corporate Code, for example, begins by stating that " $t \mathrm{t}]$ he business and affairs of every corporation organized under this chapter shall be managed by or under the direction of a board of directors . ...,

Yet this sentence of section 141(a) ends with the caveat, "except as may be otherwise provided ... in [the] certificate of incorporation." Delaware law accordingly treats board governance as a default rule that can be "bargained around" in the corporate charter. In practice, closely held companies sometimes do adopt alternatives to board governance; public corporations, however, do not. In fact, a board of directors is a near-universal feature of the publicly held firm. ${ }^{7}$

This pattern suggests that, for some reason, participants in public corporations-including investors-value director primacy. Just as the legendary Ulysses served his own interests by binding himself to the mast of his ship, investors may be serving their own interests by binding themselves to boards.

This Article explores the question of how shareholders might benefit from ceding control over their investments to boards of directors. Part I begins by surveying the widely accepted model of board function that will be referred to herein as the "monitoring" model. The monitoring model of the board posits that shareholders cede

4 The phrase "director primacy" has been used by Stephen Bainbridge to describe corporate law's strong penchant for allocating control over corporate assets and earnings to boards of directors instead of to shareholders. See, e.g., Bainbridge, supra note 1 , at 6 ("Director primacy asserts that.... [n]either shareholders nor managers control corporations-boards of directors do."); Stephen M. Bainbridge, Director Primacy: The Means and Ends of Corporate Governance, 97 Nw. U. L. REv. 547, 550-51 (2003) (discussing this pattern, but asserting that directors use their authority to serve shareholders).

${ }^{5}$ Del. CODE ANN. tit. 8, $\$ 141$ (a) (2001).

${ }^{6}$ Id.; see also infra text accompanying notes $72-73$ (discussing the default nature of most director governance rules).

${ }^{7}$ Indeed, it may be a universal feature. Although alternative governance arrangements are sometimes seen in closely held firms and LLCs and are a standard feature of partnerships, I have never seen nor heard of any large public firm opting out of board governance. Even more striking, when public corporations use charter provisions to modify the default rules of director authority, they almost always do so to strengthen rather than weaken the board's power. See infra text accompanying notes 7376 (discussing charter provisions). 
control to boards primarily because boards are in a better position than shareholders to police against the "agency costs" that corporate executives would otherwise impose on firms. The monitoring model accordingly views boards of directors as shareholder agents hired to watch over other, less-trustworthy shareholder agents.

The monitoring model is the dominant theory of board control today and offers many useful insights into the patterns of board structure and behavior that we observe. At the same time, however, Part I argues that the monitoring model is seriously incomplete because it fails to explain the fundamental attribute of public firms first highlighted by Berle and Means-extreme separation of share ownership and control. Put differently, the monitoring model explains why shareholders might hire boards of directors to advise them on how to run the firm, and especially to advise them on how and when to hire, compensate, and fire executive employees. It does not explain, however, why shareholders would take the additional (and radical) step of actually relinquishing their control over firm assets and outputs to a board that is free, as a matter of law, to ignore their wishes.

Part I argues that this separation of share ownership from control can be explained by an alternative, but less widely accepted, theory of board function described as the "mediating" model. The mediating model does not reject the idea that shareholders rely on directors to overcome the coordination problems shareholders themselves face in overseeing the firm's executives. At the same time, however, the mediating model posits that shareholders do not rely on corporate boards only to rein in executives. Shareholders also rely on boards to rein in themselves by weakening shareholder control over firm assets and outputs.

Obviously, weakening shareholder control sometimes works against shareholders' ex post interests. According to the mediating model, however, shareholders-like Ulysses-gain greater benefits from tying their own hands in this fashion. Diluting shareholder power-and with it, shareholders' ability to extract wealth from the firm-may ultimately benefit shareholders by enhancing the firm's ability to attract the firm-specific, sunk-cost investments of other important corporate "constituents," including creditors, executives, and rank-and-file employees. The mediating model accordingly does not view the separation of ownership from control accompanying board governance as a problem. Instead, the model views it as a solution.

Which of these two theories-the purely monitoring board model or the mediating board model-best captures the reality of modern 
public companies? Part II of the Article begins by observing that the answer cannot be determined at the theoretical level. Each model of board function is internally consistent and theoretically plausible. To evaluate their merits, we must look to the available empirical evidence.

Part II examines some of this evidence. It begins by inquiring which model better describes the way modern corporate governance actually functions. In many business contexts, the answer to this question is not obvious: in a number of situations where corporate law allows boards to pursue business strategies that seem to sacrifice shareholders' interests in favor of those of other constituencies, it is nevertheless possible to argue that these strategies actually serve shareholders' "long-run" interests. Such long-run arguments lose much of their traction, however, in the context that is the subject of this Symposium-change of control transactions. In this context, the extent to which corporate law follows the mediating model becomes clearly visible.

Commentators who subscribe to the monitoring model accordingly are often forced, in the change of control context, to concede that takeover law is inconsistent with a purely monitoring board. In response, they argue that this phenomenon reflects a deficiency of the law rather than a deficiency of the model. Put differently, adherents of the monitoring model argue that the legal rules governing change of control transactions are defective and in need of reform.

As Part II observes, however, this latter argument runs afoul of a second important source of empirical information about the normative value of a mediating board versus a purely monitoring board. Despite the enabling nature of corporate law, public firms generally avoid shareholder primacy-enhancing "reforms," even at the initial public offering (IPO) stage where corporate promoters have the greatest incentive and ability to select governance rules that appeal to outside investors. In fact, when firms do modify the default rules of corporate governance, they almost always move in the opposite direction, selecting charter provisions that strengthen director control over the firm. This pattern strongly suggests that investors, managers, and other corporate participants collectively perceive director primacy as advantageous ex ante.

Part III concludes by observing that, while the current empirical evidence supports the mediating model more strongly than the purely monitoring model, the question has hardly been resolved with certainty. As a result, there is much to be gained from further empirical 
inquiry. Part III points out, however, that many of the existing empirical studies that have been devised to test the monitoring model are intrinsically unable to distinguish between results consistent with the monitoring model and results consistent with the mediating model. As a result, new tests will have to be devised. In the meantime, however, it makes little sense to ignore the clear import of the data that is presently available. Absent contrary empirical evidence, the mediating model should enjoy a presumption of validity.

\section{TWO THEORIES OF DIRECTOR CONTROI.}

Directors, like Rodney Dangerfield, often get no respect. Indeed, in many discussions of corporate governance, they are implicitly denied any special role in firm governance at all, and are lumped together with the firm's executive officers under the uninformative label of "management." As a matter of law, however, the rights, privileges, and obligations of corporate directors are quite different from those of corporate executives. ${ }^{9}$ Corporate law-if not all corporate scholars-recognizes that boards of directors perform a unique function in firm governance.

What is that function? Detailed and explicit analysis of the economic role played by directors in corporations is remarkably scarce. ${ }^{10}$ Nevertheless, a reader who surveys the contemporary corporate literature quickly will find that many who write in the field share a consensus view of the role directors ought to play, at least in an ideal

${ }^{8}$ See, e.g., Robert C. ClaRk, CoRPorate LAW 23-24 (1986) (discussing the importance of "centralized management" in explaining the popularity of corporate form without distinguishing between officers and directors). Indeed, one leading text on business organizations does not even grant directors their own entry in the index, instead instructing the reader who hopes to find information on directors to " $[\mathrm{s}]$ ee Officers and Directors." William A. KLEIN \& JOHN C. COFFEe, JR., Business ORGaNIZATION AND FinANCE: LEGAL AND ECONOMIC PRinCIPLES 419 (8th ed. 2002).

${ }^{9}$ Compare DEL. CODE ANN. tit. 8, $\$ 141$ (2001) (describing the rights and duties of directors), with DEL. CODE ANN. tit. 8, $\$ 142$ (2001) (describing the rights and duties of corporate executives and officers).

${ }^{10}$ See Lynne L. Dallas, The Relational Board: Three Theories of Corporate Boards of Directors, 22 J. CORP. L. 1, 3 (1996) ("Part of the problem with the recent corporate reform debate is that it has given little attention to theories of board composition and functioning."). As an example of this inattention, the leading text on the economic functions of corporate law mentions boards in only a few pages and never explains what function they supposedly perform. FRANK H. EASTERBROOK \& DANIEL R. Fischel, THE ECONOMIC STRUCTURE OF CORPORATE LAW 2, 3, 64, 72 (1991). 
world." This consensus might be dubbed the "monitoring" model of the board.

\section{A. The Monitoring Theory of the Board}

To understand the concerns underlying the monitoring model of the board, it is useful to start with a thought experiment: imagine a firm with no board. In particular, imagine a large public company in which the decisions normally made under the directors' authority (e.g., executive hiring and compensation decisions, dividend declarations, and mergers and acquisitions strategy) instead are made by the shareholders themselves. Even a moment's reflection quickly reveals just how unsatisfactory this arrangement would be. The typical public firm has thousands or even hundreds of thousands of shareholders. How can these individuals reach a collective decision? Shareholder voting is slow, difficult, and expensive, even with modern information technology. In contrast, a board of ten or twelve members can meet and vote on these issues relatively quickly, easily, and cheaply. Director voting accordingly enjoys a clear efficiency advantage over shareholder voting as a means of making business decisions on a regular basis.

Director voting offers other important advantages over shareholder voting as well. In the typical public firm, ownership is widely dispersed, with most investors holding only a relatively small portion of the firm's outstanding shares. As a result, few shareholders have the incentive to devote much time to, or to acquire significant expertise in, the firm's affairs. Director governance helps to address such problems. By selecting a small group of individuals to specialize in the firm and its affairs, compensating them for this specialization, and providing them with information and access, director governance permits not only more efficient decision making, but more informed and intelligent decision making as well.

${ }^{11}$ For rare examples of explicit discussion of this model, see MELVIN ARON EISENBERG, THE STRUCTURE OF THE CORPORATION: A LEGAL ANALYSIS 156-170 (1976) (analyzing the functions of boards and concluding that their primary function is to monitor the self-interested actions of professional managerial employees); Stephen $M$. Bainbridge, Why A Board? Group Decisionmaking in Corporate Governance, 55 VAND. L. REV. 1, 3, 7 (2002) (noting that corporate scholarship has largely ignored the question of why firms have boards and arguing that boards, as groups, are superior to individuals in performing the central task of monitoring the firm's employees); Dallas, supra note 10, at 4-10 (discussing monitoring theories of the board as a curb on executiveimposed agency costs). 
For these and related reasons, ${ }^{12}$ there can be decisive advantages to centralizing corporate decision making in a board of directors, instead of leaving governance in the hands of a large, ever-shifting, and relatively apathetic and uninformed body of public shareholders. Yet it is important to recognize that the coordination problems associated with shareholder decision making cannot alone explain why large public corporations have boards of directors. Efficiency demands that someone other than the shareholders take the corporate helm. That "someone" need not be a board of directors.

To develop this point, consider some of the alternative solutions that might be devised to address the coordination and rational apathy problems associated with widely dispersed share ownership. One solution might be governance by a subset of the firm's shareholders-say, the ten with the largest holdings. Or, shareholders could simply rely on the firm's executive officers to make all the decisions. After all, corporate officers are full-time employees who are readily available to the firm and thoroughly familiar with its business. As a result, they can make business decisions on the firm's behalf even more efficiently, and with even better information, than a board of directors.

If shareholders cared only about informed and efficient decision making, boards would enjoy an advantage compared to shareholders themselves, but corporate officers would enjoy an advantage over directors. For this reason, shareholders' coordination problems and the need for more informal and efficient decision making cannot, alone, explain why public corporations universally opt for board governance.

Efficiency and intelligence are not the only qualities shareholders seek in centralized management, however. Shareholders are also concerned about loyalty-ensuring that whoever determines the firm's direction steers a course designed to serve the shareholders' interests. On the question of loyalty, corporate officers suffer from a distinct disadvantage. As employees of the firm, they will often face situations where the course of action that is best for themselves is not best for

${ }^{12}$ Other aspects of board structure may also promote better decisions than would be possible through shareholder voting. For example, because boards meet in person, and because most follow a norm of unanimity, a dissenting director at a board meeting has a much better chance of getting her fellow directors to listen to and take account of her views than a dissenting shareholder would have in a shareholders' meeting or a proxy battle. This may allow boards to avoid unwise choices shareholders would approve. Other dynamics of group decision making may also make boards superior to shareholders at assessing and evaluating business strategies. See generally Bainbridge, supra note 11, at 1 (arguing that advantages of group decision making help explain the use of boards). 
the shareholders. This conflict of interest is obvious in matters of executive retention and compensation, but it arises in other areas as well. ${ }^{13}$ As a result, shareholders who hire professional managers to run their firms can expect to suffer the losses. In economic parlance, executive officers are agents, and principals who employ agents incur agency costs.

This two-part analysis-which relies on directors' relative ability to make efficient and informed decisions compared to shareholders, and their relative ability to make impartial and disinterested decisions compared to officers-provides the foundation for the monitoring theory of the board. The monitoring model posits that the central economic function of the board is to reduce the agency costs that executives otherwise would impose on the firm's shareholders. Directors are in a relatively good position to perform this function because, compared to executives, they face fewer conflicts of interest, and compared to shareholders, they can more easily observe executive behavior and take responsive action. Thus, the monitoring model views directors as agents of shareholders who are employed to watch over other, less-faithful agents. ${ }^{14}$

Casual empiricism supports many aspects of the monitoring model of board function. As a practical matter, the lion's share of business decisions in most public firms are made not by directors, but by the company's executives, including the CEO. Directors, in contrast, play a passive role; boards meet infrequently, and often seem content to follow the CEO's lead except in extraordinary cases. ${ }^{15}$ The monitoring model of the board is consistent with this pattern, for it views the locus of directors' superior decision-making ability as confined primarily to areas where executive self-interest conflicts with shareholder interests (e.g., on matters of executive hiring and

${ }^{13}$ For example, self-interested executives might be tempted to use the firm's earnings to pursue acquisitions and other strategies that enlarge their "empires," instead of paying those dividends out to shareholders.

See, e.g., EASTERBROOK \& FISCHEL, supra note 10, at 76 (describing directors as agents of shareholders).

In some limited circumstances, corporate law also seems to call upon directors to act as agents for the broader society by ensuring that firms obey the law. See, e.g., Miller v. AT\&T, 507 F.2d 759, 762 (3d Cir. 1974) (noting that the business judgment rule would not protect directors who knowingly allowed the firm to violate the law).

${ }^{15}$ See CLARK, supra note 8, at 108 (observing that it is "unrealistic to view directors as making any significant number of basic business policy decisions. Even with respect to the broadest business policies, it is the officers who generally initiate and shape the decisions. The directors simply approve them, and occasionally offer advice or raise questions."). 
compensation). Outside this limited context, the monitoring model predicts that executives, not directors, will formulate business strategy and run the firm on a day-to-day basis. Boards exist primarily for oversight and intervene only in extremis.

Despite its strengths, however, the monitoring model does a remarkably poor job in one vital respect of explaining the governance of public firms. This is because the monitoring model fails to account for the extreme separation of share ownership from firm control that is the hallmark of the public firm. Put differently, the monitoring model explains why shareholders might select a small group of independent and expert outsiders whom the shareholders would pay to oversee the firm's professional managers and to advise the shareholders on management's competence and loyalty. The monitoring model does not explain, however, why shareholders would take the additional and remarkable step of turning over control of the firm, and all its assets and outputs, to these outsiders.

To understand this last point, it is useful to consider the case of a highly successful firm that has retained its earnings for years. The firm's shareholders believe the corporation cannot earn a superior return on this hoard of cash; they would prefer to distribute the money to themselves through a large dividend. The monitoring model predicts that shareholders should be able to compel the board to do this. After all, the board is supposedly the shareholders' "agent," and the shareholders are supposedly the firm's sole residual claimants, entitled to every penny the firm earns above the amount needed to pay the contractual claims of employees, creditors, and suppliers.

The default rules of corporate governance do not, however, follow the predictions of the monitoring model. Shareholders cannot pay themselves dividends; if a dividend is declared at all, it must be declared by the board. ${ }^{16}$ If the board refuses to declare a dividend, in the typical public firm there is little the shareholders can do about it. Even if the shareholders delivered a unanimous resolution requesting a dividend to the board, the board would be legally free to ignore it. ${ }^{17}$ And any threat to vote the board out of office is likely to sound a bit

${ }^{16}$ See Del. Code ANN. tit. 8, $\$ 170$ (2001) (authorizing only directors to declare dividends); see also Gabelli \& Co. v. Liggett Group, Inc., 479 A.2d 276, 280 (Del. 1984) ("It is settled law in this State that the declaration and payment of a dividend rests in the discretion of the corporation's board of directors in the exercise of its business judgment.").

${ }^{17}$ See CLARK, supra note 8, at $372-73$ (stating that shareholders' voting rights are limited and that the board is legally free to ignore most resolutions). 
hollow: proxy contests and hostile takeover bids pose little danger to incumbent directors of public corporations with widely dispersed shareholders and well-chosen antitakeover defenses. ${ }^{18}$

It is difficult to reconcile this fundamental reality of corporate law with the monitoring model's hypothesis that directors are shareholders' "agents." Boards do, of course, have the power to limit how much of the corporation's returns are allocated to its executives. But boards also have the power to limit how much of the returns from corporate production are allocated to shareholders. ${ }^{19}$ Furthermore, shareholders in public corporations seem to happily tolerate this arrangement, even though the enabling nature of corporate law allows them to opt out of it. ${ }^{20}$

Such observations naturally suggest that, in addition to expecting boards to monitor executives' performance, shareholders also expect-or at least anticipate-that board governance will have the additional effect of reducing their own ability to extract wealth from the firm. This second aspect of board governance seems, on first inspection, to clearly work against shareholders' interests. Closer analysis reveals that shareholders may not only tolerate, but actually prefer, to "tie their own hands" in this fashion.

\section{B. The Mediating Theory of the Board}

To understand how shareholders can benefit by insulating boards from their own command and control, it is important to recognize that executives are not the only actors in the firm who can exploit other corporate participants. Nor do shareholders always play the role of exploited victim; to the contrary, shareholders are sometimes the exploiters.

${ }^{18}$ See infra text accompanying notes 53-58, 61-68 (discussing the difficulties shareholders encounter in ousting boards).

${ }^{19}$ The monitoring model accordingly raises, but provides no answer to, the question, "who watches the watchers?" For example, self-interested directors might retain corporate earnings in order to expand their own empires, rather than return those earnings to shareholders in the form of dividends. Similarly, they might choose to sooth employee unrest through unnecessary wage concessions, thus purchasing a "quiet life" at the shareholders' expense. As a result, it can be argued that if the monitoring model is correct, the board is a dysfunctional institution because director governance simply adds another layer of agents who are in a position to impose costs on shareholders. But of. infra text accompanying notes 36-42 (explaining why boards make sense under the mediating model).

${ }^{20}$ For a discussion of alternative governance structures that would allow shareholders to enjoy the monitoring benefits of a board without ceding as much control, see infra text accompanying notes 72-73. 
This possibility is well-recognized in the corporate literature. Although contemporary scholarship tends to focus almost obsessively on the problem of deterring corporate executives from imposing "agency costs" on shareholders, ${ }^{21}$ well-developed literatures detail how shareholders can opportunistically exploit creditors (e.g., by pursuing very high-risk projects) $;^{22}$ how some shareholders can exploit other shareholders (e.g., by "freezing" them out, or by threatening to withdraw their resources from the firm) $;^{23}$ and how shareholders can turn the "agency cost" tables and take advantage of executives and other corporate employees (e.g., by first leading them to believe their hard work will be rewarded by future raises or job security, and then firing them). ${ }^{24}$ Such opportunistic shareholder behavior is sometimes

${ }^{21}$ This Symposium, for example, contains numerous articles that focus primarily on the problem of protecting shareholders from executive misbehavior: Jennifer Arlen \& Eric Talley, Unregulable Defenses and the Perils of Shareholder Choice, 152 U. PA. L. REV. 577 (2003); Lucian Arye Bebchuk, Why Firms Adopt Antitakeover Arrangements, 152 U. PA. L. REV. 713 (2003); Lawrence Hamermesh, Premiums in Stock-for-Stock Mergers and Some Consequences in the Law of Director Fiduciary Duties, 152 U. PA. L. REV. 881 (2003); Marcel Kahan \& Edward B. Rock, Corporate Constitutionalism: Antitakeover Provisions as Precommitment, 152 U. PA. L. REV. 473 (2003); Richard E. Kihlstrom \& Michael L. Wachter, Corporate Policy and the Coherence of Delaware Takeover Law, 152 U. PA. L. REV. 523 (2003).

${ }^{22}$ See, e.g., Gulati et al., supra note 1, at 912 (noting that equity-holders have an incentive to choose riskier projects, which increase the value of their claim and reduce the value of the debtholders' claim); Laura Lin, Shift of Fiduciary Duty Upon Corporate Insolvency: Proper Scope of Directors' Duty to Creditors, 46 VAND. L. REV. 1485, 1511 (1993) (" $[\mathrm{C}]$ orporate restructuring may impose greater risk of loss on bondholders and thus transfer wealth from bondholders to shareholders."); Thomas A. Smith, The Efficient Norm for Corporate Law: A Neotraditional Interpretation of Fiduciary Duty, $98 \mathrm{MICH}$. L. REV. 214, 228 (1999) ("Investors who own much more of the firm's equity than its debt may push managers to adopt inefficient strategies that increase the value of the firm stock but decrease the value of the firm debt by more.").

${ }^{23}$ See, e.g., Margaret M. Blair, Locking in Capital: What Corporate Law Achieved for Business Organizers in the 19th Century, 51 UCLA L. REV. (forthcoming 2004) (discussing how incorporation can minimize the risk that a shareholder might try to withdraw her investment to the detriment of other shareholders); Frank H. Easterbrook \& Daniel R. Fischel, Close Corporations and Agency Costs, 38 STAN. L. REV. 271, 296 (1986) (discussing fiduciary duties and rights that help "minority shareholders protect themselves against opportunistic behavior by the majority, [but also create] incentives for the minority to behave opportunistically toward the majority to extract disproportionate concessions"); Edward B. Rock \& Michael L. Wachter, Waiting for the Omelet to Set: Match-Specific Assets and Minority Oppression in Close Comporations, 24 J. CORP. L. 913, 914-15 (1999) (outlining "several repeated scenarios that raise the issue of "minority oppression"" by majority shareholders); Robert B. Thompson, Corporate Dissolution and Shareholders' Reasonable Expectations, 66 WASH. U. L.Q. 193, 196-97 (1988) (noting that majority interests can manage the affairs of the corporation in ways that oppress the minority shareholders).

${ }^{24}$ See, e.g., John C. Coffee, Jr., The Uncertain Case For Takeover Reform: An Essay on Stockholders, Stakeholders, and Bust-Ups, 1988 WIS. L. REV. 435, 439-40 (claiming that 
described in terms of "shareholder oppression," "implied contracts," or even "bilateral agency costs." A number of recent writings, however, including my own and those of Margaret Blair and Lynn LoPucki, describe the problem as one of corporate team production. ${ }^{25}$

other firm stakeholders "are exposed ... to shareholder opportunism"); Charles R. Knoeber, Golden Parachutes, Shark Repellents, and Hostile Tender Offers, 76 AM. ECON. REV. 155,166 (1986) ("Where contracting between managers and shareholders is an important source of discipline on manager behavior and where the best contract is implicit with much compensation delayed until manager performance can be better evaluated, managers may fear that a hostile tender offer will provide shareholders with an avenue for opportunism."); Andrei Shleifer \& Lawrence H. Summers, Breach of Trust in Hostile Takeovers, in CORPORATE TAKEOVERS: CAUSES AND CONSEQUENCES 33, 37-42 (Alan J. Auerbach ed., 1988) (discussing the importance of trust between shareholders and stakeholders so as to avoid exploitation).

${ }^{25}$ See, e.g., Blair \& Stout, supra note 1, at 418-22 (discussing the team production analysis and directors' roles as mediating hierarchs); Blair \& Stout, supra note 3, at 250 ("In the economic literature, team production problems are said to arise in situations where a production activity requires the combined investment and coordinated effort of two or more individuals or groups."); Lynn M. LoPucki, A Team Production Theory of Bankruptcy Reorganization, 57 VAND. L. REV. (forthcoming Apr. 2004), available at http://lawweb.usc.edu/faculty/workshops/documents/LoPucki.pdf (discussing how team production has important implications for understanding bankruptcy law); Stout, supra note 1, at 1195-99 (discussing the team production argument against shareholder primacy); Lynn A. Stout, Do Antitakeover Defenses Decrease Shareholder Wealth? The Ex Post/Ex Ante Valuation Problem, 55 STAN. L. REV. 845 (2002) ("Modern corporate production ... is a form of team production."); see also ROBERT W. HAMILTON, CASES AND MATERIALS ON CORPORATIONS 26-29 (7th ed. 2001) (citing Blair \& Stout's theory that the corporation is a nexus of specific investments in team production); CHARLES R.T. O'Kelley \& ROBERT B. ThOMPSON, Corporations and Other Business ASSOCIATIONS 7-9 (3d ed. 1999) (explaining the problems of organizing production as an implicit team); Allen Kaufman et al., A Team Production Model of Corporate Governance Revisited (Sept. 2003) (unpublished manuscript, on file with author), available at http://papers.ssrn.com/sol3/papers.cfm?abstract_id=410080 (discussing team production in corporations); Peter C. Kostant, Team Production and the Progressive Corporate Law Agenda, 35 U.C. DAVIS L. REV. 667, 668-69 (2002) (“[T] he new Team Production Model [TPM] .... is a powerful economic model that helps shift the law away from an overly narrow concern merely for shareholders. TPM is useful for a broader understanding of corporate social responsibility."); Alan J. Meese, The Team Production Theory of Corporate Law: A Critical Assessment, 43 WM. \& MARY L. REV. 1629, 1632 (2002) (discussing Blair \& Stout's argument and stating that "the public corporation is best viewed as a team of shareholders, creditors, workers, managers, and communities"); David Millon, New Game Plan or Business As Usual? A Critique of the Team Production Model of Corporate Law, 86 VA. L. REv. 1001, 1003 (2000) (recounting Blair \& Stout's argument that, in understanding the "various participants in the corporation as a team, [the team production model] describes the directors as independent 'mediating hierarchs whose job it is to balance team members' competing interests' ...." (quoting Blair \& Stout, supra note 3, at 280-81)); Lawrence E. Mitchell, Trust and Team Production in Post-Capitalist Society, 24 J. CoRP. L. 869, 871 (1999) (asserting that increased trust can help solve the team production problem); D. Gordon Smith, Team Production in Venture Capital Investing, 24 J. CORP. L. 947, 960-962 (1999) (describing the moral hazard problem in venture capital financed corporate teams); Eric Talley, Taking the 
Team production analysis of the public corporation begins with the observation that it takes more than shareholders' money to make a corporation. After all, a pile of money sitting alone does nothing: creating a productive firm requires other investments as well. Executives must invest skill and creativity, employees must put in time and effort, and local governments may offer tax breaks and specialized infrastructure. Moreover, shareholders are not the only financial investors in the firm; creditors often provide funding as well. Corporate production accordingly is a form of team production involving the inputs of many team members. ${ }^{26}$ Many of these inputs may be essential to the success of the enterprise.

How can shareholders induce nonshareholder groups to make their essential contributions? One obvious inducement is a formal contract that promises specific rewards in return for a specific contribution. For example, a senior executive may work in part because she has negotiated an explicit and legally enforceable compensation package that includes wages, deferred compensation, insurance, and other perquisites. Yet economic analysis of the team production problem teaches that in a world of uncertainty and imperfect information, formal contracting can go only so far. This is especially true when team members' contributions become "team-specific," meaning they cannot be easily withdrawn from the team and sold for their full value elsewhere. ${ }^{27}$ In such cases, it can become impossible to draft formal

\footnotetext{
"I" Out of "Team": Intra-Firm Monitoring and the Content of Fiduciary Duties, 24 J. CORP. L. 1001, 1002 (1999) ("In its most basic form, the team-production account spotlights the observation that productive activities within many economic organizations require coordinated, firm-specific investments from two or more participants."); $c f$. Rock \& Wachter, supra note 23, at 919 (discussing the problem of shareholder oppression in close corporations and inherent team production problems in terms of "match-specific investments in a context with substantial asymmetry of information").

${ }^{26}$ See generally Blair \& Stout, supra note 3, at 271-76 (modeling a typical team production situation where each team member contributes to corporate output). Although this Article focuses primarily on the corporate contributions of shareholders and executive officers, other groups, such as creditors, rank-and-file employees, and even governments, also can make essential contributions to corporate team production in public firms. See id. at 250,278 (noting the various groups that can contribute to team production); see also Stout, supra note 1, at 1195 ("[C] reditors, employees, managers, and even local governments often must make contributions in order for an enterprise to succeed.").

${ }^{27}$ See infra pp. 681-82 (discussing the concept of team-specific resources); see also O'KELLEY \& THOMPSON, supra note 25, at 7-9 (explaining team-specific investment and the problems that result).
} 
contracts that protect corporate team members from each other's opportunism. $^{28}$

To gain a quick sense of how difficult contracting over team production can be, consider the problems involved in drafting a simple contract between two individuals to move a large sofa. Moving a sofa is a classic example of team production; it takes two to do the job, and each mover's effort is essential. Yet if the movers agree ex ante to share their profits according to a fixed formula, each will have an incentive to shirk, in the hopes of leaving the other to carry more than her share of the load. This is because each mover gets all of the benefits from shirking, but bears only part of the cost. Conversely, if the movers agree to wait until after the job is done to split the profits according to who worked hardest, their investment in the job becomes team-specific: neither can recover the value of her effort except by sharing in the team's profits. As a result, each mover now has the incentive to "rent seek" by claiming more than her fair share because each knows the other is vulnerable and cannot now withdraw her efforts.

Ex ante formal contracting would be much easier if the movers could employ a machine that measures exactly how much effort each person expends. However, such devices do not exist, even for the straightforward task of moving furniture. The ex ante contracting problem becomes far more intractable when we are trying to measure exactly the efforts that go into the far more complex task of building a successful business.

Consider the example of a start-up corporate team formed by two individuals: an investor who contributes cash and a professional manager who provides ideas, expertise, and time. As in the sofa-moving example, each team member's contribution swiftly becomes, at least in part, team-specific. After the investor's money has been used to purchase specialized equipment and pay salaries, she cannot recover the full value of those funds except by waiting to see if the venture is successful. Similarly, after the manager has expended time and effort, or acquired firm-specific human capital (knowledge, skills, and contacts that are uniquely valuable to the firm and cannot be sold elsewhere), she cannot earn a return from those investments except by waiting until the venture begins to produce profits. lems).

${ }^{28}$ See generally Blair \& Stout, supra note 3, at 265-69 (discussing contracting prob- 
As this example illustrates, team production often requires team members to contribute assets that, once committed to team production, cannot be withdrawn and sold elsewhere for their full value. In economic parlance, the contributions become team-specific. ${ }^{29}$ Firmspecific human capital is one classic example of a team-specific resource. The concept of team specific investment is much broader, however, and also encompasses past investments of time and effort made in the expectation of future rewards. ${ }^{30}$ Thus "team-specific investment" and "sunk-cost investment" are used as synonyms in this Article.

Having made specific investments, each team member now finds herself vulnerable to the other's opportunism in ways that formal contracting can do little to eliminate. For example, suppose that the manager, eager to ensure a return on her sunk-cost investments of time and skill, demands a contract that entitles her for some period to a salary, some percentage of the venture's profits, and a generous severance package (or "golden parachute"). The investor will rightly worry that this arrangement creates incentives for the manager to shirk-she gets only part of the returns from working hard, but all of the returns from shirking (not to mention the tempting opportunity to be paid for not working if the parachute is deployed). Conversely, suppose the investor, to prevent shirking, demands a contract that provides the manager will be paid in proportion to her efforts and investments, will have no golden parachute, and can be fired at any time for cause. The manager will rightly worry that, after she has made her sunk-cost investments, the investor might try to deny her a just share of the resulting profits by claiming she did not use her best efforts, or perhaps even try to fire her for cause.

As an alternative, the parties can try to tie the manager's salary to some "objective" measure of performance, such as share price. Yet, in the common situation where performance is not perfectly

29

See, e.g., Margaret M. Blair \& Lynn A. Stout, Team Production in Business Organizations: An Introduction, 24 J. CORP. L. 743 (1999) ("[S]ome of the resources the team members must invest to produce are 'team-specific,' meaning they have a significantly higher value when used in the team than in their next best use."); Charles R. O'Kelley, Jr., Filling Gaps in the Close Corporation Contract: A Transaction Cost Analysis, 87 NW. U. L. REV. 216, 222 (1992) (describing a team-specific contribution as "an asset ... [with] value that cannot be realized by putting the asset to another use"); see also Vincent $P$. Crawford, Relationship-Specific Investment, 105 Q.J. ECON. 561, 566 (defining a "sunk-cost investment" as an asset "that cannot be withdrawn[,]" consumed, or reinvested elsewhere).

${ }^{30}$ See Blair \& Stout, supra note 3, at 272-76 (discussing the various types of investments that are team-specific). 
observable-remember the sofa-movers-a truly accurate and objective performance signal will not exist. As a result, contracts based on signals are not only difficult and expensive to negotiate and draft, but are also inflexible, unresponsive to unanticipated changes in circumstances, and create their own opportunities for rent-seeking. ${ }^{31}$ Suppose, for example, the firm's share price drops after a competitor enters the market. The investor can claim opportunistically that the loss was due to the manager's bungling. In the same vein, the manager can argue that she deserves a raise because only her extraordinary efforts kept the stock price from dropping even further.

Team production analysis accordingly teaches that it is not only possible for corporate executives to opportunistically impose "agency costs" on shareholders-it is also possible for shareholders to opportunistically impose "agency costs" on executives and other nonshareholder groups that make sunk-cost investments in the corporate team. To observers accustomed to focusing on the myriad ways in which corporate executives can take advantage of rationally apathetic shareholders, the observation that the exploitation can run in the opposite direction may seem counterintuitive. Nevertheless, this "man bites dog" scenario is not only theoretically possible, but quite plausible in the business world.

To understand why, consider again the example of the start-up venture organized by the investor and the manager. Assume the parties initially agree that if the manager does a good job and things go well, the investor will reward her with future job security, raises, and perks. (This sort of understanding is common in many employment relationships.) Five years later, the business is successful, with annual sales of $\$ 110,000$. At this point, the manager is being paid compensation and benefits that total $\$ 100,000$ annually. Assume that only ten percent of this amount reflects extracontractual returns on the manager's extracontractual sunk-cost investments; the manager could earn $\$ 90,000$ if she abandoned her investment in the team and sought employment elsewhere. Finally, assume for simplicity that the manager's compensation and benefits are the firm's only expenses.

Now suppose the investor decides to opportunistically claim that the manager's performance is subpar, a claim that the manager would find expensive and difficult to contest in court. At this point, the investor could lower the manager's annual compensation to $\$ 90,001$ and still keep her in the firm. This ten percent reduction in 
the manager's returns would allow the investor to nearly double her annual profits, from $\$ 10,000$ to almost $\$ 20,000$. $^{32}$

This example demonstrates how shareholders can face tempting opportunities for rent-seeking in any firm where payments to nonshareholders are large relative to net profits (a common business scenario) and even a modest percentage of those expenses reflect extracontractual payments for sunk-cost investments (also a common pattern). ${ }^{33}$ Recognizing this threat, stakeholders might be justifiably reluctant to make extracontractual specific investments in a public firm where shareholders enjoy unalloyed control. For similar reasons, shareholders might be reluctant to invest in a firm where stakeholders (e.g., executives) hold all the power. The end result is that investment may not occur at all, and the firm may never come into being.

Team production analysis consequently casts a spotlight on the often-overlooked problem of how we can induce the various constituencies of a public corporation to make specific investments that cannot be protected by contract or other solutions. ${ }^{34}$ In a series of recent articles written by Margaret Blair and myself, ${ }^{35}$ we have explored the idea that boards of directors-in addition to any advantages they offer shareholders in public firms by monitoring executives-may also play

${ }^{32}$ Alternatively, the investor might sell the firm to a hostile bidder who intends to replace the manager or to reduce her compensation and benefits. In the above hypothetical, such a bidder would be willing to pay up to a one hundred percent premium for control over the firm. This is a considerably larger premium than actually paid in most hostile acquisitions. See Lucian Arye Bebchuk et al., The Powerful Antitakeover Force of Staggered Boards: Theory, Evidence, and Policy, 54 STAN. L. Rev. 887, 926 tbl.2 (2002) (finding a thirty-seven percent average premium in hostile deals in a recent five-year sample). A corollary is that all or part of the premiums paid in some hostile takeovers may reflect wealth transfers from employees and managers to stockholders. See Stout, supra note 25 , at 853.

${ }^{33}$ This example is based on a similar one presented in Shleifer \& Summers, supra note 24 , at 36 .

${ }^{34}$ Formal contracting is not the only possible solution to this investment problem. In small firms, for example, or those with a controlling shareholder, investors and professional managers may often interact face-to-face and rely on interpersonal trust and trustworthiness to discourage opportunism. See Margaret M. Blair \& Lynn A. Stout, Trust, Trustworthiness, and the Behavioral Foundations of Corporate Law, 149 U. PA. L. REV. $1735,1799-1807$ (2001) (exploring the role of trust in private firms). Market forces, including concern for business reputation, can also police against exploitative behavior among team members in some situations, such as when venture capitalists act as "repeat players" in the market for start-up firms. See D. Gordon Smith, Venture Capital Contracting in the Information Age, 2 J. SMALL \& EMERGING BUS. L. 133, 157 (1998) (examining the "market for reputation").

${ }^{95}$ Blair, supra note 23; Blair \& Stout, supra note 1; Blair \& Stout, supra note 29; Blair \& Stout, supra note 3; Stout, supra note 1; Stout, supra note 25. 
an essential role in addressing this problem. This argument is summarized below.

As previously discussed, corporate production often requires a number of groups besides shareholders to make sunk-cost investments that cannot be adequately protected by formal contract or market mechanisms. As a result, a number of groups in addition to shareholders are potential "resịdual claimants" or "residual risk-bearers" in the firm. These nonshareholder groups recognize that if the shareholders were given unalloyed control of the firm, they would not necessarily use that control to maximize profits for all team members. Instead, shareholders might extract wealth from other team members by threatening to destroy or expropriate their specific investments. Similarly, if managers or creditors were given complete control, they might also engage in rent-seeking.

To address this problem of mutual opportunism, corporate team members prefer to cede control over both the firm and their sunkcost, team-specific investments to an outside party that is not itself a residual claimant and thus lacks any direct incentive to take advantage of team members. This outside party is the board of directors. Directors, in their positions as directors, are not entitled to dividends, interest payments, or salaries. ${ }^{36}$ By tradition, they receive only a flat fee for their services, and a relatively modest one at that (although it may not seem modest to underpaid academics). ${ }^{37}$ Thus directors-unlike

${ }^{36}$ Individuals who sit on corporate boards may receive significant dividends, interest payments, or salaries if, in addition to their board positions, they also own a large number of shares, hold substantial corporate debt, or are employed by the firm. In such a case, a director may be tempted to rent-seek by using her power as a director to further her interest as a shareholder, creditor, or employee. To some extent, the duty of loyalty polices against such behavior. See infra note 38. To the extent that it does not, the director's ability to act as a disinterested mediator is reduced. This may explain why, as of the late $1990 \mathrm{~s}$, seventy percent of large firms chose to have boards with a majority of "independent" directors who were not also employees of the firm. John C. Coates IV, Measuring the Domain of the Mediating Hierarchy: How Contestable Are U.S. Public Corporations?, 24 J. CORP. L. 837, 844-45 (1999). It also raises questions about the wisdom of compensating directors with stock or stock options, a practice that has become common at many companies in recent years. By making directors large shareholders, this practice may also make boards less likely to resist opportunistic shareholder attempts to extract wealth from other corporate constituencies, thereby discouraging these constituencies' extracontractual investments.

${ }^{37}$ See CLARK, supra note 8, at 108-09 (“[D]irectors typically receive a flat yearly fee that is unrelated to their performance on behalf of the shareholders."); Lynn A. Stout, On the Proper Motives of Corporate Directors (Or, Why You Don't Want to Invite Homo Economicus to Join Your Board), 28 DEL. J. CORP. L. 1, 4 (2003) (observing that directors' fees normally can be measured in tens of thousands of dollars, which is not a large amount to a successful businessperson). 
shareholders, creditors, executives, or employees-have relatively little opportunity or incentive to use their corporate positions to enrich themselves at other corporate participants' expense. ${ }^{38}$

Corporate law accordingly gives the board-and not the shareholders or the CEO-ultimate control over the corporation's assets. Similarly, corporate law gives the board discretion to allocate the returns generated by corporate assets among various team members. Shareholders and nonshareholders alike prefer this arrangement. By making the directors the "mediating hierarchs" of the firm, they tie their own hands, reducing their ability to take advantage of each other. The end result is to encourage the sorts of committed investments that cannot be protected fully by formal contract, yet may be essential to business success.

It is important to note that directors can fulfill this hands-tying function without consciously intending to act as mediators among the firm's various constituencies. Of course, many directors do view themselves as mediators trying to balance shareholders' interests against those of creditors, employees, and the like. ${ }^{39}$ Nevertheless, directors do not have to think of themselves this way to perform a mediating function. Board governance by its very nature makes it more awkward and difficult for any of the constituencies of a public company to withdraw resources from the firm. Shareholders who want a dividend, executives who want their options repriced, and creditors who want their debt restructured must all go before the

${ }^{38}$ Because of the protection directors enjoy from the business judgment rule in cases that do not involve a direct conflict between the director's personal economic interests and those of the firm, the principal constraint on directors is the duty of loyalty, which prevents directors from using their corporate positions to increase their own wealth. See Blair \& Stout, supra note 3, at 298-99 (discussing the duty of loyalty). Duty of loyalty rules perform an essential function under the mediating model by ensuring that directors are not residual claimants of the firm. Id. A corollary of this view is that governance arrangements that make directors residual claimants-e.g., rules that compensate directors primarily in stock or rules that allow inside directors to enter interested transactions with the firm-undermine the mediating role and invite in trateam rent-seeking. See supra note 36.

${ }^{39}$ See, e.g., Unocal Corp. v. Mesa Petroleum Co., 493 A.2d 946, 955 (Del. 1985) (noting that directors may act out of concern for other constituencies, including employees and the community, in their decision making); Credit Lyonnais Bank Nederland, N.V. v. Pathe Communications Corp., No. 12150, 1991 Del. Ch. LEXIS 215, at *108 n.55 (Del. Ch. Dec. 30, 1991) ("[D] irectors will recognize that . . circumstances may arise when the right (both the efficient and the fair) course to follow for the corporation may diverge form the choice that the shareholders (or the creditors, or the employees, or any other single group interested in the litigation) would make."), affd sub nom. Solomon v. Pathe Communications Corp., 672 A.2d 35 (Del. 1996). 
board to make a case requesting such action. This need to offer a justification, alone, can discourage more blatant attempts at rentseeking, and even a well-reasoned request may be turned down by the board. Thus, board governance increases the cost and risk associated with intrateam rent-seeking, discouraging ex post opportunism and encouraging ex ante investment in team production.

The mediating model of the board, like the monitoring model, accordingly does not view directors as superior corporate decision makers for all the firm's decisions, but only for an important subset of decisions: those that involve a conflict between corporate constituencies that the constituents themselves have been unable to negotiate and have instead opted to kick "upstairs" (at some risk to both sides) for the board's resolution. ${ }^{40}$ Like the monitoring model, the mediating model leaves day-to-day operations and most business strategizing largely to company executives.

Unlike the monitoring model, however, the mediating model does not confine the directors' role only to limiting how much wealth the firms' executives extract from the firm. Directors also limit how much wealth is distributed to the firm's shareholders, creditors, and even to the local community. Thus the board not only has the ultimate say in hiring and compensating executives-it also has the ultimate say in whether the firm will pay dividends, recapitalize in a fashion that helps debtholders, or pursue or abandon a merger or an asset sale that might harm employees and the local community.

The mediating model of the board accordingly differs from the monitoring model in that it does not view directors only as fiduciaries of shareholders. Directors are also fiduciaries of the firm itself, an entity that can be understood as a nexus of firm-specific commitments made by investors, managers, and other corporate constituencies. ${ }^{41}$ Thus, where the monitoring model casts suspicion on any board decision to use firm assets to provide extracontractual benefits to nonshareholders (e.g., by providing employees with better health care coverage or by making donations to local charities), the mediating model takes a benign view of such discretionary, extracontractual

${ }^{40}$ As a practical matter, it can be expected that many potential conflicts among corporate team members will never be put before the board for resolution because the team members involved, recognizing that they are acting in the shadow of the board, work out compromises among themselves. For example, faced with unrest among rank-and-file employees, executives may voluntarily increase employee wages while refraining from asking for large bonuses for themselves.

41 See Blair \& Stout, supra note 3, at 285-86 (discussing the corporation as the nexus of firm-specific investments). 
expenditures. Far from being evidence of malfeasance or "managerial slack," director largesse toward nonshareholders is the natural and anticipated outcome of governance by a mediating board. Similarly, extracontractual payments to managers or employees are not inefficient "private benefits" or "agency costs" to be eliminated, but evidence of efficient, surplus-producing team production.

The benefits that director governance provides in terms of encouraging team-specific investment are not, of course, costless. It is important to recognize that the mediating model of board governance does not assume or require that directors have a particularly robust incentive to maximize returns on the firm's investments once they have been made. (This lack of incentive can be disturbing to those who favor the monitoring model on the theory that shareholders, whom the monitoring model inaccurately depicts as the firm's sole residual claimants, have such an incentive.) The mediating model simply assumes that directors want to get, and keep, their positions as directors. Thus, directors have incentive to help bring the public firm into existence and to encourage corporate constituencies to make specific investments. Having accomplished this, the board also has an incentive not to let the firm fall apart. As a result, the board will want to ensure that each essential team member receives enough of a return on its investment to induce it to remain on the team instead of seeking outside opportunities. Beyond this minimum standard, however, the board does not have a particularly strong motive to maximize returns to shareholders, managers, or other residual claimants. Although directors probably want their firms to grow in order to expand their own "empires," they do not have an especially keen drive to maximize returns on firm assets.

The mediating model thus predicts that after firms are created, we can expect boards to run them in a satisficing, but suboptimal, fashion. The result is an "agency cost" borne not just by shareholders, but by all the investing members of the corporate team. As a result, a mediating board is clearly only a second-best solution to the problem of encouraging sunk-cost investment in corporate production. ${ }^{42}$

Yet it is important to recognize that the monitoring board is also only a second-best solution to the problem of executive-imposed agency costs. A board that serves only the shareholders' interests would not seek to maximize returns on all the firm's investments any more than a mediating board would. Instead, it would seek to

${ }^{42}$ See id. at 283-84 (discussing the mediating board as a second-best solution). 
maximize only returns to shareholders-sometimes by expropriating wealth from other team members. The result may be to discourage nonshareholders from making extracontractual contributions. For example, consider how a firm's executives, employees, and creditors would likely behave if they believed the firm's shareholders could, at any time, require the board to withhold all extracontractual benefits from these groups and instead pay out every penny of excess return to the shareholders. Would they put in the extra hours, extra effort, and extra patience in hard times that make a business succeed?

Investors who are deciding between investing in a firm governed by a mediating board and investing in a firm governed by a purely monitoring board accordingly find their choice boils down to the question: Which is more important to business success? The ex ante advantage of getting corporate constituents to make extracontractual specific investments in the firm in the first place? Or, the ex post advantage of optimizing shareholders' subsequent returns from that firm without these investments? To paraphrase Winston Churchill, the mediating board may be the worst possible form of public corporation governance-except for the alternatives.

\section{EMPIRICAL EVIDENCE}

As noted in Part I, most contemporary corporate scholars subscribe to the monitoring model of board function, which confines director decision making primarily to overseeing the firm's executive officers. This model, however, does not adequately explain the extreme separation of share ownership and firm control that we observe in public companies. That separation seems more consistent with the mediating model, which views directors as decision makers not only with regard to the distribution of corporate wealth to managers, but also with regard to the distribution of corporate wealth to shareholders, creditors, employees, and other stakeholders.

Despite the intellectual dominance of the monitoring model in contemporary scholarship, both models claim a long and respectable lineage. The argument that boards ought to act as faithful agents of shareholders can be traced back at least to a 1931 article by Adolph Berle in the Harvard Law Review. ${ }^{43}$ Similarly, while the emerging literature on team production offers new and useful insights into how

49 Adolf A. Berle, Jr., Corporate Powers as Powers in Trust, 44 HARv. L. REv. 1049, 1049 (1931) (arguing that corporations' powers should be used "only for the ratable benefit of all the shareholders"). 
director control can benefit shareholders by promoting other stakeholders' ex ante team-specific investment, ${ }^{44}$ variations on the mediating model can be found in the scholarly literature dating back at least to the $1980 \mathrm{~s}^{45}$ and the general idea that directors should be free to take account of stakeholders' interests appears much earlier. ${ }^{46}$ Indeed, in the Harvard Law Review issue that followed the publication of Berle's shareholder primacy thesis, Professor Merrick Dodd argued that directors should seek to advance the interests not only of shareholders, but of employees, managers, and the community as well. ${ }^{47}$

As this long tradition of disagreement suggests, one cannot reject either the monitoring board hypothesis or the mediating board hypothesis at the theoretical level. Both models are intellectually sound and internally consistent. This may explain why the "Great Debate," as it was recently characterized by Delaware Vice Chancellors Leo Strine and Jack Jacobs and former Chancellor Bill Allen, ${ }^{48}$

${ }^{44}$ Team production analysis can help, for example, shed light on the nature of the firm, see Blair \& Stout, supra note 3, at 271-76 (describing the firm as a nexus of firm-specific commitments that are not protected by contract or otherwise); the terms of the "implied contract" entered into between and among team members, $i d$. at 277 78 (viewing contract as a pact to participate in a process of mutual goal-setting and dispute resolution under the ultimate authority of a board); and the rationale for a variety of otherwise-puzzling corporate law doctrines, id. at 290-315 (describing how team production analysis helps explain rules of legal personality, fiduciary duty, and shareholder voting).

${ }^{45}$ See, e.g., Coffee, supra note 24 , at 448 (" $[\mathrm{T}]$ he parties to the implicit contract need an independent body to serve as, in effect, an arbitration panel to preserve the fair expectations of each side."); Knoeber, supra note 24, at 157-66 (arguing that implicit contracting between managers and shareholders for golden parachutes and shark repellents is advantageous to both parties); Shleifer \& Summers, supra note 24, at 41-42 (arguing that takeovers breach implicit contracts between shareholders and managers, potentially discouraging the latter's specific investments in the firm); see also EISENBERG, supra note 11, at 159-62 (discussing the board's potential role as "modality" for shareholder and nonshareholder groups to influence managers' decisions).

${ }^{46}$ See, e.g., BERLE \& MEANS, supra note 2, at 356 ("It is conceivable[]-indeed it seems almost essential if the corporate system is to survive[]-that the 'control' of the great corporations should develop into a purely neutral technocracy, balancing a variety of claims by various groups in the community and assigning to each a portion of the income stream ....").

${ }^{47}$ See E. Merrick Dodd, Jr., For Whom Are Corporate Managers Trustees?, 45 HARV. L. REV. 1145, 1148 (1932) ("[P]ublic opinion ... has made and is today making substantial strides in the direction of a view of the business corporation as an economic institution which has a social service as well as a profit-making function ....").

${ }^{48}$ See William T. Allen et al., The Great Takeover Debate: A Meditation on Bridging the Conceptual Divide, 69 U. CHI. L. REV. 1067, 1067 (2002) ("We begin a new century with a debate that is old but persistent. ... [T] he question is whether corporation law exists solely in order to facilitate shareholder economic welfare or whether ... [it] represents 
between those who believe directors should serve only shareholders and those who believe directors should have discretion to serve stakeholder groups as well, continues to be unresolved. Nevertheless, while the mediating model enjoys substantial support among those who actually participate in or advise the business community, the monitoring model is more widely accepted among academics today. Many, if not most, contemporary corporate law casebooks and scholarly articles implicitly or explicitly subscribe to the notion that the principal job of the board is to protect shareholders by limiting the "agency costs" executives would impose. ${ }^{50}$

Why does the purely monitoring model dominate over the mediating model in academic circles? The reason seems to lie in a common perception that a mediating board, while possible in theory, is implausible in practice. For example, theorists have argued that, as a practical matter, firm-specific investment is not important to corporate production; that nonshareholder groups, as a practical matter, can protect their investments adequately through formal contracts; and that the mediating model is unworkable because, as a practical matter, directors cannot be expected to do a good job of looking out for the interests of nonshareholder constituencies. ${ }^{51}$

a partial commitment by the law to values in addition to implementing shareholder will.").

For example, as John Coates has observed, academics tend to disapprove of antitakeover defenses as contributing to the problem of agency costs, while businesspeople and regulators generally support them. See John C. Coates IV, Takeover Defenses in the Shadow of the Pill: A Critique of the Scientific Evidence, 79 TEx. L. REV. 271, 273 (2000) (" $[\mathrm{A}]$ cademics generally have taken a dim view of takeover defenses, and practicing lawyers have generally supported defenses in advising clients, with judges and legislators siding more with practitioners than with academics.").

50 See Blair \& Stout, supra note 3, at 248 n.1 (citing "voluminous" literature adopting the monitoring model). It should be noted, however, that, while the monitoring model is more widely accepted among academics, there is no shortage of scholars to argue that directors should be willing and able to serve a wide range of corporate constituencies. See id. at 253 n.16 (citing works that adopt the "stakeholder" approach); see also supra note 25 (citing casebooks and articles that discuss team production).

${ }^{51}$ See, e.g., EISENBERG, supra note 11, at 162 (concluding on the basis of empirical speculations that "[o]n balance, therefore, the importance of the board's modality function ... is questionable as to clients and social groups"); Lucian Arye Bebchuk, The Case Against Board Veto in Comporate Takeovers, 69 U. CHI. L. REv. 973, 1022-26 (2002) (arguing against the mediating board on the assumption that directors cannot do a good job of looking after the interests of nonshareholders); Michael Klausner, Institutional Shareholders, Private Equity, and Antitakeover Protection at the IPO Stage, 152 U. PA. L. REV. 755, 782-84 (2003) (rejecting the team production explanation of antitakeover defenses as efficient supports for director primacy as a theoretical possibility that, in the author's view, based on empirical speculations, seems "doubtful"); Jonathan R. Macey, Externalities, Firm-Specific Capital Investments, and the Legal Treatment 
These arguments cannot be rejected a priori. Nevertheless, their strength ultimately depends on factual assumptions about the nature of the business world. Critiques of the mediating model accordingly can be reduced to empirical claims that, for a variety of reasons, even if a mediating board can add value to a firm in theory, it is unlikely to do so in practice. Such claims can be tested. Put differently, the longstanding debate between proponents of the monitoring model of the board and proponents of the mediating model is an empirical argument that can only be resolved satisfactorily by empirical inquiry-not by armchair speculation. To choose between the two models, one needs evidence.

This Part examines some of that evidence. Empirical observation strongly suggests that the mediating model of the board provides a better positive description of the way corporate law actually works than the dominant monitoring model. This strength is especially apparent in the area of corporate law that is the subject of this Symposium-change of control transactions.

\section{A. The Empirical Case for the Mediating Model as a Positive Description of Board Function}

In evaluating the relative empirical strength of the monitoring model versus the mediating model, it is useful to begin by asking which model does a better job of describing how board governance actually works in modern firms. After all, it is standard practice for economists to judge the value of models primarily by their ability to predict observed phenomena. One of the most significant phenomena observed in public corporations is a dramatic separation between share ownership and control over corporate assets. Any model of the public corporation that fails to predict this fundamental characteristic is deeply flawed. ${ }^{52}$

When this basic criterion-the ability to predict the separation of ownership from control--is applied to the mediating and monitoring models of board function, the mediating model seems, on first inspection, to be far superior. ${ }^{53}$ After all, the monitoring model predicts that

of Fundamental Corporate Changes, 1989 DUKE L.J. 173, 188-92 (arguing that, as an empirical matter, nonshareholders can protect themselves through contracts).

${ }^{52}$ See Bainbridge, supra note 11, at 45 (arguing that a primary criterion for evaluating any model of the corporation should be the model's ability to predict the separation of share ownership from control).

${ }^{53}$ See Allen et al., supra note 48, at 1079 ("Delaware law inclines toward the entity [mediating board] model. Indeed, it must be acknowledged that ... Delaware law af- 
directors should act as shareholders' agents. This idea implies both that boards ought to run firms solely in shareholders' interests, and that when boards fail to do this, shareholders collectively ought to be able to intervene and make boards dance to their tune. The default rules of corporate law clearly do not follow this prediction. To the contrary, as long as directors do not use their powers to line their own pockets, ${ }^{54}$ they enjoy legal discretion to run the firm pretty much as they please, including discretion to pursue corporate strategies that benefit nonshareholder groups at the shareholders' expense and over the shareholders' clear and unanimous objections. Thus directors legally can refuse to pay dividends; can reprice executives' options; can retroactively increase retirees' pensions; can shift to expensive but "socially responsible" production methods; and can even donate corporate funds to charity. If a firm's shareholders pass a unanimous resolution requesting a board to stop doing such things, the board is free to ignore it. ${ }^{5 \overline{5}}$ If the shareholders bring suit, the directors are protected by the business judgment rule. ${ }^{56}$ And, as Berle and Means famously pointed out, if the shareholders try to vote the directors out of office, they likely will be defeated by their own rational apathy. ${ }^{57}$

The end result is that directors of public firms enjoy, as a legal and practical matter, an extremely wide range of autonomy to sacrifice shareholders' interests in order to serve other corporate stakeholders. That range is not unlimited, but it is far too broad to be consistent with the monitoring model's prediction that directors are shareholders' "agents." G8 Given this obvious contradiction, it seems

fords the directors room to consider the interests of other constituencies ...."); Leo E. Strine, Jr., The Social Responsibility of Boards of Directors and Stockholders in Charge of Control Transactions: Is There Any "There" There?, 75 S. CAL. L. REV. 1169, 1176 (2002) (noting that outside the context of the Revlon case, Revlon, Inc. v. MacAndrews \& Forbes Holdings, Inc., 506 A.2d 173 (Del. 1986), the mediating model prevails in corporate law).

${ }_{55}$ See supra note 38 (discussing the duty of loyalty).

${ }^{55}$ See Blair \& Stout, supra note 3, at 290-91 (discussing directors' authority to ignore shareholders' resolutions).

${ }^{56}$ See id. at 299-305 (discussing the business judgment rule).

${ }^{57}$ See BERLE \& MEANS, supra note 2, at 80-82 (discussing obstacles to collective shareholder action).

${ }_{58}$ It might be argued that, even if corporate law permits directors to sacrifice shareholders' interests in order to serve those of other constituencies, market pressures, including the pressures of the product market, the capital market, and the market for corporate control, force directors to steer in the direction of shareholder primacy. A moment's thought reveals that this is not necessarily the case for the product market: director concern for consumers is hardly likely to make it more difficult for a firm to sell its products. Similarly, the possibility that directors might favor creditors can only enhance a firm's ability to issue debt, which is a more important source 
curious that more scholars have not questioned the descriptive validity of the monitoring model.

Two possible explanations come to mind for why the conflict between observed corporate governance patterns and the notion that directors work only for shareholders often goes unremarked. The first explanation hinges on the observation that, in many situations where boards sacrifice shareholders' returns to provide benefits to nonshareholders, such actions can be rationalized, however implausibly, as serving shareholders' long-run interests. ${ }^{59}$ For example, a decision to retroactively increase retirees' pensions can be defended as contributing to higher employee morale that in turn increases productivity, and a decision to donate corporate funds to local charities can be defended as a purchase of valuable community goodwill. Thus in many cases where boards use their control over corporate assets to provide benefits to nonshareholder groups beyond those required by contract, it remains possible to dispute, or at least to gloss over, the extent to which this pattern undermines the empirical validity of the purely monitoring model.

There is a second, and arguably more significant, reason why the discrepancies between the predictions of the monitoring theory and the realities of modern corporate governance are often overlooked. This is the common belief that, even if the law does not require directors to maximize shareholders' returns, market forces-especially the market for corporate control-may do so. This belief can be traced back to the development and refinement during the 1970s and 1980s of the hostile tender offer as a vehicle for allowing hostile acquirers to do an "end run" around the boards of target firms by assembling a controlling block of shares from the target's widely dispersed shareholders and then using this newly created control block to displace the board. The result, many argued, was an active "market for corporate control" that would swiftly punish any board that failed to keep its stock price high and its shareholders happy. ${ }^{60}$

of capital for seasoned firms than equity. And while in theory an active market for corporate control pressures directors to favor shareholders' interests, in practice hostile takeovers do not pose much of a threat to incumbent boards. See infra text accompanying notes 60-69 (discussing limits on the market for control).

${ }_{59}$ See, e.g., Paramount Communications, Inc. v. Time, Inc., 571 A.2d 1140, 1151-55 (Del. 1989) (allowing the directors of Time to reject a hostile offer at a very large premium on the grounds that the shareholders' "long-term goals" would be better served by merging Time with another company favored by Time's board).

${ }^{60}$ See, e.g., Frank H. Easterbrook \& Daniel R. Fischel, The Proper Role of a Target's Management in Responding to a Tender Offer, 94 HARV. L. REV. 1161, 1169 (1981) ("The 
It is vital to note, however, that hostile tender offers only became common in the 1970s and early 1980s as a result of structural and cultural changes in the investment banking industry that made financing hostile bids feasible. Before these changes, hostile acquisitions were unusual and unlikely. ${ }^{6 \prime}$ Additionally, it took only a few years for businesses to counter the emerging takeover threat by developing an impressive array of defensive tactics that would-be targets could use to fend off unwanted suitors. By the mid-1980s, for example, it had become common practice for directors of potential targets to shield themselves from the threat of a hostile bid by deploying the newly created antitakeover defense known as the "poison pill." Similarly, when hostile bidders turned to proxy battles to oust recalcitrant boards, directors at many established firms and a majority of new firms quickly responded by adopting "classified board" provisions. ${ }^{63}$

Accordingly, an active market for corporate control existed, to the extent it did so at all, during only a fraction of the time the public corporation has been the dominant form of business in the United States. Today, incumbent directors of public companies have every opportunity-through poison pills, staggered board provisions, and other defenses, including incorporating in states with antitakeover statutes-to insulate themselves from all but the most persistent, wealthy, and lucky suitors. Nevertheless, memories of the 1970s and 1980s linger. With them perhaps lingers the perception that the dynamic takeover market of the 1970s and early 1980s was somehow "normal," while the relative security incumbent boards enjoy today is the aberration. From a historical perspective, the reverse is true.

This last observation points to an important irony-it is the change of control context that, in many ways, provides the strongest evidence for the descriptive accuracy of the mediating board model. Consider the example of a hostile acquirer that wants to buy all of a

tender bidding process polices managers ... and disciplines or replaces them if they stray too far from the service of the shareholders."); Ronald J. Gilson, A Structural Approach to Corporations: The Case Against Defensive Tactics in Tender Offers, 33 STAN. L. REV. $819,841-42$ (1981) (discussing the shareholders' option to sell depressed stock to new owners, who would then replace the ineffective management team).

${ }^{61}$ See generally Martin Lipton, Pills, Polls, and Professors Redux, 69 U. CHI. L. REv. $1037,1039-50$ (2002) (describing the rise of the hostile tender offer in the 1970s and the development of the poison pill and various antitakeover rules in the 1980s in response).

62 See id. at 1044 (noting the "increasing use of the pill in 1984-85").

${ }^{63}$ See infra text accompanying notes 74-76 (discussing the rise of staggered board provisions and their role in preventing hostile takeovers). 
target firm's outstanding shares in a cash merger at a fifty percent premium over market price. Suppose the target's shareholders enthusiastically and unanimously support the merger, while the firm's executive and employees oppose it. Most commentators believe that, under Delaware law, the board is free to favor the employees' desires over those of the shareholders by "just saying no" and refusing to sell the firm. ${ }^{64}$ Moreover, it is clear that the board can protect the executives and employees by seeking out a friendly merger with a public firm, even if this means the shareholders will receive a lower price. ${ }^{65}$ Only if the directors make the obvious and avoidable mistake of seeking refuge in the arms of a private company (thus putting the target into so-called "Revlon mode") is a court likely to intrude on the board's authority, and possibly oblige it to favor the shareholders by selling the firm to the highest bidder. ${ }^{66}$

Change of control transactions consequently provide some of the best illustrations of the remarkable degree of discretion corporate law grants directors to favor nonshareholder interests at the shareholders' expense. They also highlight how easily boards can insulate themselves from the supposed pressures of the "market for corporate control." Finally, change of control transactions draw attention to the

${ }^{64}$ See Bebchuk et al., supra note 32, at 906 (claiming that Delaware case law gives directors the right to "just say no" to a hostile bid); Mark Gordon, Takeover Defenses Work. Is That Such a Bad Thing?, 55 STAN. L. REV. 819, 820-22 (2002) (noting that directors can "just say no" by refusing to redeem the company's poison pill); Leo $\mathrm{E}$. Strine, Jr., The Professorial Bear Hug: The ESB Proposal as a Conscious Effort to Make the Delaware Courts Confront the Basic "Just Say No" Question, 55 STAN. L. REV. 863, 876 (2002) (emphasizing that poison pills allow directors to reject bids, but that shareholders retain the power to remove the board through a proxy fight).

${ }^{65}$ See Stout, Bad and Not-So-Bad, supra note 1, at 1203-04 (noting that directors can avoid Revlon duties by seeking a stock-for-stock exchange with another public firm).

${ }^{66}$ See id. (arguing that directors are only obliged to seek the highest price for shareholders if they are accepting a deal that would take a public company private); see also Revlon, Inc. v. MacAndrews \& Forbes Holdings, Inc. 506 A.2d 173, 182, 185 (Del. 1986) (holding that when the directors of a public company decide to sell to a company with a controlling shareholder, effectively turning a public company into a private one, the board has a duty to maximize shareholder wealth by getting the best possible price for the firm's shares).

Revlon describes the one context where Delaware law appears to abandon director primacy for shareholder primacy. Stout, supra note 1, at 1203-04. Subsequent cases have drastically diminished Revlon's importance by holding that if directors decide not to sell, or if they pursue a stock-for-stock merger with another public firm, Revlon is inapplicable. Id.; see also Paramount Communications, Inc. v. Time, Inc., 571 A.2d 1140 (Del. 1990) (holding that Revlon duties were not implicated in a stock-for-stock exchange). As a result, directors can avoid falling into Revlon mode when they wish. Stout, supra note 1 , at 1204. 
weakness of arguments based on shareholders' "long-run" interests. It is hard to claim with a straight face that a particular firm's shareholders will be better off in the long run if they are denied the chance to sell their shares at a hefty premium, especially when those shareholders eagerly wish to become ex-shareholders. ${ }^{67}$ To advance such an argument, one must claim both that the shareholders are underestimating the value of their holdings by an amount greater. than the premium (fifty percent or more in many cases) and that the firm's directors for some reason cannot possibly persuade the shareholders of their own foolishness. ${ }^{68}$ Arguments for director primacy based on shareholders' long-run interests accordingly tend to lose, in the takeover context, whatever traction they may enjoy in other situations.

It is accordingly extremely difficult to defend the descriptive accuracy of the monitoring model of board function in the change of control context. A corollary of this observation is that commentators who favor the monitoring model of the board often argue that when it comes to control transactions, the default rules of corporate law are defective and need to be reformed. Thus, corporate theorists who adhere to the monitoring model shift from arguing that the model is an accurate positive description of how public corporations actually are governed to arguing that the monitoring model provides an attractive normative template for how public corporations ought to be governed. The result is a vast (and still-growing) body of literature critiquing the many and varied aspects of corporate law that insulate directors of public firms from an active "market for corporate control."

${ }^{67}$ This is not to say that allowing boards to reject a premium bid might not serve the long-run interests of shareholders as a class, nor that such director discretion might not also serve the ex ante interests of the shareholders of the particular firm being targeted. Indeed, this is the basic idea underlying the mediating model. See supra text accompanying notes $33-38$.

${ }^{68}$ See Bebchuk, supra note 51, at 997-1007 (arguing that despite their informational disadvantage, shareholders, not boards, should have the final decision as to whether the share price offered is sufficient). But see Kihlstrom \& Wachter, supra note 21, at 574 (reasoning that allowing shareholders to determine the sufficiency of an offer price increases overall agency costs).

${ }^{69}$ A large body of literature implicitly adopts the monitoring model and argues that antitakeover defenses increase agency costs by impeding the market for corporate control. Recent examples include Bebchuk, supra note 51, at 975; Bebchuk et al., supra note 32, at 950-51; Robert B. Thompson \& D. Gordon Smith, Towuard A New Theory of the Shareholder Role: "Sacred Space" in Copporate Takeovers, 80 TEx. L. REv. 261, 326 (2001). Earlier arguments in this vein can be found in Easterbrook \& Fischel, supra 
This shift from a positive to a normative perspective raises its own empirical difficulties for the monitoring model, however. In particular, the claim that investors would prefer a purely monitoring board to a mediating board is seriously undermined by several recent studies of firm behavior in selecting charter provisions before an IPO.

\section{B. The Empirical Case for the Mediating Board as a Normative Prescription}

As noted earlier, many modern corporate codes generally treat director governance as a default rule. ${ }^{70}$ Most significantly, section 141 (a) of the Delaware Code, while providing for board governance, allows this pattern to be modified in the certificate of incorporation. ${ }^{71}$ Similarly, section 102(b) (1) authorizes incorporators to include in a corporate charter "[a]ny provision for the management of the business and for the conduct of the affairs of the corporation, and any provision creating, defining, limiting and regulating the powers of the corporation, the directors, and the stockholders. ${ }^{72}$

Delaware corporate law accordingly authorizes incorporators to adopt charter provisions that modify the conventional rules of board governance. For example, a firm could adopt a charter provision that provides for governance by the firm's five largest shareholders. Or, it could permit shareholders to elect the CEO directly, while also electing an advisory board of outsiders to monitor the CEO's performance and make recommendations about when and by whom the CEO should be replaced. (Under this system, instead of turning control of the firm over to directors, shareholders simply pay them for their advice.) Alternatively, shareholders could maintain an option on firm control by delegating broad authority to the board while retaining the right to veto board decisions. This approach would grant the board a default right to manage the firm while still requiring the directors to comply with any shareholder resolution approved by holders of a

note 60, at 1164; and Ronald J. Gilson, The Case Against Shark Repellent Amendments: Structural Limitations on the Enabling Concept, 34 STAN. L. REV. 775, $778-79$ (1982).

${ }^{70}$ See supra text accompanying notes 6-7 (discussing board governance as a default rule and a feature of public corporations).

${ }^{71}$ DEL. CODE ANN. tit. 8, \$ 141(a) (2001).

${ }^{72}$ Id. $\$ 102(\mathrm{~b})$ (1) (emphasis added). For an example of how corporate participants sometimes contract around the default rules of director governance, see Credit Lyonnais Bank Nederland, N.V. v. Pathe Communications Corp., No. 12150, 1991 Del. Ch. LEXIS 215 (Del. Ch. Dec. 30, 1991) (describing a complex governance agreement adopted at a financially troubled firm that limited the directors' authority), aff'd sub nom. Solomon v. Pathe Communications Corp., 672 A.2d 35 (Del. 1996). 
majority of the firm's shares. Less ambitiously, promoters could simply employ charter provisions that preclude boards from adopting poison pills or similar takeover defenses without shareholder approval. Any or all of these measures are available to the incorporator who believes investors want greater control over boards.

Remarkably, public corporations as a rule do none of these things. ${ }^{73}$ To the contrary, when the charters of public firms do depart from the default rules of corporate governance, they almost always move in the opposite direction through modifications that strengthen directors' power vis-a-vis shareholders. This pattern has been observable to some extent since the days of Berle and Means. It has become far more visible in recent years, however, as a result of several newly published studies of the charter provisions of firms selling shares to outside investors in IPOs. ${ }^{74}$

IPO studies have consistently found that, in the years following the takeover battles of the 1970s and early 1980s, a substantial and increasing percentage of firms "going public" have chosen to include provisions in their charters making it more difficult for either the firm's shareholders or a hostile acquirer to oust an incumbent board. A common example is a "staggered" board structure that allows only one-third of the firm's directors to face reelection in any one year. ${ }^{.5}$ Between the late 1980s and the late 1990s, depending on the time period observed, the incidence of IPO firms whose charters provided for a staggered board rose from around one-third to over eighty percent. $^{76}$

${ }^{73}$ See, e.g., John C. Coates IV, Explaining Variation in Takeover Defenses: Blame the Lawyers, 89 CAL. L. REV. 1301, 1397 (2001) (observing that charter prohibitions that restrict directors' power to use poison pills "are so rare as to be almost nonexistent for research purposes").

${ }^{74}$ Id. at $1377-78$ (analyzing takeover defenses adopted by IPO firms); Robert Daines \& Michael Klausner, Do IPO Charters Maximize Firm Value? Antitakeover Protections in IPOs, 17 J.L. ECON. \& ORG. 83, 95-110 (2001) (evaluating antitakeover provisions in IPO charters); Laura Casares Field \& Jonathan M. Karpoff, Takeover Defenses of IPO Firms, 57 J. FIN. 1857, 1858-62 (2002) (examining the incidence of antitakeover measures in IPO firms).

${ }^{75}$ This requires a hostile bidder who wants to try to replace incumbent directors via a proxy battle to win at least two elections and to endure a delay of at least one year. See generally Bebchuk et al., supra note 32, at 902-24 (discussing staggered boards and their negative effect on takeover bids).

${ }^{76}$ Coates, supra note 73, at 1376 (finding that the incidence of staggered boards in IPO firms rose from $34 \%$ in 1991-92 to $82 \%$ in 1999); see also Daines \& Klausner, supra note 74, at 95 (noting that more than $40 \%$ of firms evaluated in the authors' sample adopted a staggered board); Field \& Karpoff, supra note 74, at 1861, 1884 
Such findings offer at least two important insights into the debate between those who support the monitoring model of the board and those who favor the idea that boards also serve a mediating function. First, they further undermine the positive version of the monitoring board hypothesis. A recent study has concluded, for example, that since the development of the poison pill, allowing directors the additional protection of a staggered board structure makes it virtually impossible for a hostile bidder to acquire control of a target firm through a proxy contest. ${ }^{77}$ Thus, as more public firms adopt a staggered board structure, it becomes increasingly unrealistic to argue that directors of such firms are driven to serve only shareholders' interests out of the fear that, if they do not, they will be disciplined in an active market for corporate control.

Second, and more importantly, the observation that firms going public for the first time prefer to adopt charter provisions enhancing board authority also poses a direct challenge to any normative claim for the superiority of the monitoring board. Prospective investors in an IPO can readily determine the contents of the firm's charter and the degree to which directors are insulated from shareholder challenge. If investors believe that ceding control to a board will likely reduce their future returns, they can adjust their willingness to pay for the firm's shares accordingly. As a result, corporate promoters planning to take their firms public have every incentive to structure their firms to appeal to outside investors. If they do not, it will be the promoters, not the investors, who make less money.

The end result is that, when the public corporation is first being created-in effect, when the various groups that expect to participate in the firm are negotiating the terms of their future relationshipsthe parties that comprise "the firm" have a mutual interest in selecting efficient governance rules that maximize the firm's expected future value. Contrary to the predictions of the monitoring model, they pick rules that protect director primacy. ${ }^{78}$

(reporting that 53\% of sampled IPO firms from 1988-1992 had at least one antitakeover provision, while over $36 \%$ included a staggered board provision in their charter).

${ }^{7}$ See Bebchuk et al., supra note 32, at 890-91 (stating that from 1996-2000, no hostile bidders were successful in gaining control of a firm with a staggered board through a proxy contest).

${ }^{78}$ Several recent studies of firm behavior suggest a similar pattern in selecting states of incorporation. Corporate law is mostly state law, and a corporate promoter can select which state's laws will apply to her firm by choosing a state of incorporation. If shareholder primacy rules increase investors' returns (as the monitoring model implies), we would expect to see public stock promoters incorporate their firms in states 
This empirical reality casts new light on the monitoring versus mediating board debate. IPO studies establish that, at the IPO stage, investors display a "revealed preference" for director primacy rules in public corporations. In lay terms, investors act as if they value corporate governance rules that place control of the corporation firmly in the boards' hands more than rules that leave more control in shareholders' hands. Neoclassical economic analysis generally presumes that revealed preferences reflect actual preferences. ${ }^{79}$ As a result, IPO charter studies support a presumption in favor of the claim that investors in public corporations not only do not object to governance by a mediating board-they actually desire it.

This claim finds further support in what might be viewed as a recent natural experiment: the rise and subsequent swift fall of an active market for corporate control in the 1970 s and early 1980s. As noted earlier, it was only after the development of the financed hostile tender offer that directors of public firms became subject to what business scholars soon were enthusiastically describing as the "discipline" of that market. ${ }^{80}$ The business world, however, declined to warmly embrace the prospect of weaker board control. Within a

with rules that favor shareholder control over director primacy. For example, promoters might be attracted to California, which has no antitakeover statute and has not yet validated an important type of poison pill. See Field \& Karpoff, supra note 74, at 1865 (describing how California has no significant antitakeover laws); Guhan Subramanian, The Influence of Antitakeover Statutes on Incorporation Choice: Evidence on the "Race" Debate and Antitakeover Overreaching, 150 U. PA. L. REV. 1795, 1854-55 (2002) (observing that California has no antitakeover statutes). Conversely, they would avoid incorporating in states like Delaware and Nevada, which reinforce director primacy through antitakeover statutes and case law. See Field \& Karpoff, supra note 74, at 1865 (describing how Delaware law discourages takeovers); Subramanian, supra, at 1856-57 (describing how Nevada law discourages takeovers). Instead, the opposite pattern exists-states with relatively strong director primacy rules do better at attracting new firms and retaining old ones than states whose laws seem more "shareholder friendly." See, e.g., Lucian Bebchuk et al., Does the Evidence Favor State Competition in Corporate Law?, 90 CAL. L. REv. 1777,1821 (2002) (finding that states with antitakeover statutes are more likely to retain in-state companies and attract out-of-state companies); Field \& Karpoff, supra note 74, at 1865 (noting that twenty-three percent of IPO firms reincorporated in a new state within two years before going public, with the majority reincorporating from states with relatively unrestricted takeover laws to states with more restrictive laws); Subramanian, supra, at 1844 (noting migration toward states with antitakeover provisions, while also noting some migration away from states with especially severe antitakeover laws).

${ }^{79}$ For the classic formulation of the idea that preferences can be revealed through actual market choices, see PAUL A. SAMUELSON, FOUNDATIONS OF ECONOMIC ANALYSIS (1947).

${ }^{80}$ See supra text accompanying notes 60-61 (discussing the rise of an active market for corporate control). 
few years, state legislatures responded to hostile tender offers by passing a variety of antitakeover statutes; directors responded by deploying poison pills and other defenses; corporate promoters responded by adopting antitakeover charter provisions in new firms; and courts responded by approving most of these developments. ${ }^{81}$

To the observer who subscribes to the monitoring model, the decades between the rise of the large public firm in the 1920s and the appearance of the hostile tender offer in the 1970s-decades during which directors of public corporations were largely insulated from external threats to their incumbency-may seem an unfortunate period in which boards refused to act as shareholders' agents and instead stood by as executives built lavish empires and otherwise imposed "agency costs" on equity investors. ${ }^{82}$ Conversely, the appearance of a lively takeover market in the 1970s and 1980s was a welcome development that improved corporate governance by allowing shareholders to punish directors who failed in their monitoring role. From this perspective, corporate America's subsequent wagon-circling response in the form of poison pills, classified board provisions, and the like (not to mention judges' and legislators' apparent acceptance of this response) must seem both puzzling and disappointing.

The mediating model, however, offers a different interpretation of these events. If director governance does indeed perform an important economic function by tying shareholders' hands in a fashion that encourages other corporate team members' specific investments, it makes sense that the business world would embrace corporate law's default rules of director primacy in the decades prior to the control battles of the 1970s and 1980s. It also makes sense that, when director primacy was threatened by the unexpected advent of the hostile tender offer, corporations responded quickly and effectively with poison pills, staggered boards, and similar devices. Furthermore, it makes sense that corporate regulators smiled benignly on this defensive response. Finally, it makes sense that these director primacy protecting strategies are now adopted not only by existing firms, but also by newly created firms selling shares to public investors for the first time.

${ }^{81}$ See supra text accompanying notes 61-69, 75-76 (assessing the response to the market for corporate control).

${ }_{82}$ See, e.g., Henry Hansmann \& Reinier Kraakman, The End of History for Corporate Law, 89 GEO. L.J. 439, 444 (2001) (discussing the "manager-oriented" model of governance and arguing that the appeal of this model, popular in the 1930s through 1960 s, was "largely destroyed" in the 1970s and 1980s). 


\section{DIRECTIONS FOR FURTHER EMPIRICAL INQUIRY}

Empirical observations of corporate governance patterns, and especially studies of IPO charters, strongly suggest that the conventional monitoring model fails to capture the reality of modern public corporation boards. At the positive level, IPO studies demonstrate that directors of newly public companies enjoy a degree of discretion to sacrifice shareholders' interests to serve those of other constituencies that is inconsistent on its face with the monitoring model's premise that directors are shareholders' agents. At the normative level, IPO studies cast doubt on whether shareholders even want directors to act as their agents. At the time when they have the greatest leverage to demand optimal corporate governance rules, investors display a remarkably strong and consistent revealed preference for rules that limit their own power and place control in the hands of a board instead. This strongly suggests that the time has come for the monitoring model to lose its privileged status.

Yet the observation that IPO studies make it unreasonable to continue to unhesitatingly rely on the monitoring model does not imply that one can; without more, safely assume the validity of the mediating model. Investors' revealed preference for governance rules that favor director primacy support a presumption that investors in fact expect such rules to make them better off. Presumptions can be overcome, however. Thus, some theorists have suggested recently that IPO studies do not necessarily disprove the monitoring model because imperfections in the IPO market prevent investors from expressing their real preferences for more shareholder control. ${ }^{89}$ Given the oddities of the IPO market, including persistent underpricing, this argument has some appeal. ${ }^{84}$

${ }^{83}$ See, e.g., Field \& Karpoff, supra note 74, at 1885 (briefly discussing the possibility that promoters adopt inefficient charter provisions); LUCIAN ARYE BEBCHUK, ASYMMETRIC INFORMATION AND THE CHOICE OF CORPORATE GOVERNANCE ARRANGEMENTS 28 (John M. Olin Ctr. for Law, Econ., \& Bus., Harv. Law Sch., Discussion Paper No. 398, 2002), available at http://www.law.harvard.edu/programs/olin center/corporate_governance/papers/pdf/No398.02. Bebchuk.pdf (arguing that asymmetric information in the IPO market may explain why investors who dislike board governance nevertheless cannot "punish" IPO firms that adopt director primacy rules by discounting the price they are willing to pay for shares).

${ }^{84}$ Perhaps the best-developed version of this argument can be found in a recent paper by Lucian Bebchuk. See BEBCHUK, supra note 83 . Using the example of antitakeover charter provisions, Bebchuk argues that firms may adopt inefficient provisions that harm shareholders more than they benefit incumbent managers because it is difficult for investors to observe the intrinsic values of firms. Id. Bebchuk hypothesizes that high-value firms offer professional managers the opportunity to extract more in 
Thus the stage is set for what is likely to be the next round of the "Great Debate": the search for persuasive evidence that, after accounting for the ex ante effects of director primacy rules in encouraging specific investments, as well as their ex post effects in increasing agency costs, such rules actually leave investors worse off. Where can we find such evidence?

This inquiry is only beginning. Nevertheless, it is essential to recognize from the start that at least two forms of evidence which are commonly offered in support of the monitoring model nevertheless cannot be relied upon to overcome the implications of 'PO studies.

First, the mediating model's hypothesis that shareholders enjoy a net benefit from director primacy rules cannot be overcome by evidence that, after shareholders have chosen to buy shares in a firm governed by a mediating board, they sometimes complain ex post about having given up control to that board. Shareholders obviously can suffer after the fact from director primacy rules that allow boards to favor other constituencies. Yet, the mediating model suggests how shareholders may receive greater benefits ex ante if those same rules encourage other constituencies to make extracontractual, sunkcost investments in the firm. Antitakeover provisions, for example, can provide equity investors with an extremely valuable ex ante benefit by encouraging professional managers to endure low-pay, high-risk, long nights, and years of hard work with no vacations. Although it is impossible to draft formal contracts that reliably elicit

"private benefits" (agency costs) than low-value firms. Id. As a result, antitakeover provisions are proportionately more valuable to managers of high-value firms. Id. Nevertheless, because investors cannot directly observe firm values, they value all firms at the average. Id. Similarly, when they observe antitakeover provisions, they discount their willingness to pay for shares by the average cost of such provisions. The end result is a cross-subsidy: antitakeover provisions are proportionately less costly to high-value firms than low-value firms. If large enough, this cross-subsidy can make antitakeover provisions cost-effective at large firms. And if high-value firms start adopting antitakeover provisions, low-value firms may too, in order to avoid signaling that they are low-value. Id.

Bebchuk's argument is intriguing but rests on strong assumptions. For example, it assumes that investors cannot observe individual firms' values at all. Yet if this were true, one would expect the IPO market to implode into a classic "market for lemons" in which high-value firms refuse to participate because they do not receive full price for their shares, while low-value firms-"lemons"-rush into the market. See generally George Akerlof, The Market for "Lemons": Quality Uncertainty and the Market Mechanism, 84 Q.J. ECON. 488, 488 (1970) (discussing the incentive for sellers to market poor-quality merchandise when buyers cannot judge the quality of goods, decreasing the average quality of goods and size of the market). 
such contributions, they can be essential to a business's success, and even its survival.

Nevertheless, after the firm's managers have made sunk-cost investments in reliance on a firm's antitakeover defenses, shareholders may be tempted to try to remove the defenses and sell their shares at a premium to a bidder who will bring in a new management team. ${ }^{85}$ Such attempts at ex post rent-seeking are hardly surprising. They should not, however, be mistaken for evidence that shareholders do not benefit from and prefer the mix of corporate governance rules they elected into ex ante.

This analysis reveals the weakness in the arguments of commentators who point to such ex post evidence (e.g., shareholder proposals to eliminate existing antitakeover defenses such as poison pills or classified boards) to prove that shareholders are harmed by antitakeover provisions. ${ }^{86}$ Taken alone, the fact that shareholders sometimes protest antitakeover rules in seasoned firms, or even try to remove them, cannot overcome the presumption that investors generally accept director primacy rules at the IPO stage because they expect to receive a net benefit. After all, Ulysses also complained ex post about his bindings.

A second type of empirical evidence that is sometimes cited in support of the monitoring model are findings that director primacy rules allow nonshareholder groups to extract benefits from firms at shareholders' expense. This evidence, however, cannot be relied upon as support for the monitoring model once one acknowledges the possibility of team production concerns in public corporations. An example of this kind of empirical argument can be found in a recent study of antitakeover defenses in IPO firms by Laura Field and Jonathan Karpoff. $^{87}$ Field and Karpoff began their analysis by noting the inherent tension between the monitoring model's prediction that antitakeover provisions harm investors and the empirical observation that many firms adopt such provisions at the IPO stage. Reflecting the intellectual dominance of the monitoring model, Field and Karpoff

${ }^{85}$ See supra text accompanying notes 24, 32-33 (discussing shareholder opportunity to exploit managers' specific investment). Similarly, after shareholders have made their specific investments, professional managers may be tempted to add new and unanticipated takeover defenses to the firm's charter in a mirror-image attempt to exploit equity investors by "changing the rules in the middle of the game."

${ }^{66}$ See, e.g., Bebchuk et al., supra note 32, at 891-92 (asserting that shareholder proposals to end staggered boards are evidence that this antitakeover device reduces shareholder wealth).

${ }^{87}$ Field \& Karpoff, supra note 74, at 1884-85. 
did not discuss-much less attempt to test-the mediating model's hypothesis that antitakeover protections benefit shareholders at the IPO stage by encouraging nonshareholders' specific commitments. Instead, they focused primarily on distinguishing between two other possible explanations for why IPO firms adopt antitakeover defenses: (1) that market imperfections allow corporate promoters to opportunistically insert, at investors' expense, provisions that reduce firm value (the agency cost thesis) and (2) that antitakeover provisions benefit shareholders by allowing them to pay executives lower salaries (the substitution hypothesis). ${ }^{88}$

Examining a sample of over one thousand firms that went public between 1988 and 1992, Field and Karpoff tested how the presence of an antitakeover defense correlated with executive compensation. They found that IPO firms with defenses paid their executives more in salary in the year prior to the IPO than did firms without defenses. From this, they concluded that antitakeover protections do not serve as an efficient substitute for executive compensation, but instead allow executives to inefficiently impose greater agency costs on a firm's shareholders. ${ }^{89}$

Such findings are susceptible to another interpretation, however. Team production analysis suggests that antitakeover defenses will provide greater ex ante benefits to shareholders in companies where employees' firm-specific investments are more important to business success. Thus, if high salaries reflect the relative importance of human capital investment relative to financial capital, it makes sense to

${ }^{88}$ Id. at 1867 . Field and Karpoff ran a second test to determine whether antitakeover provisions increased shareholders' ex post returns by giving boards bargaining power to demand higher premiums from would-be acquirers. See id. at 1873-81 (finding the evidence did not support this theory); see also supra text accompanying notes 64-68 (discussing and rejecting the argument that antitakeover defenses are consistent with the monitoring model because directors use them to prevent shareholders from selling at too low a price).

${ }^{89}$ Field \& Karpoff, supra note 74 , at 1873 . Field and Karpoff also found that antitakeover provisions are negatively correlated with the age of the firm's CEO and with the percentage of stock retained by the firm's officers and directors after the offering is complete. Id. at 1868,1870 tbl.VI. They concluded that this finding also supported the agency cost thesis, on the theory that a young CEO is more eager to protect her ability to opportunistically extract private benefits than an older CEO, and that managers also are more likely to impose value-reducing antitakeover defenses on a firm if they own relatively few shares. Id. at 1870-71; see infra note 90 (discussing how these findings also support mediating theory). 
expect more antitakeover provisions at firms where managers also are paid higher salaries. ${ }^{90}$

As this example illustrates, almost any variable one might use as a proxy for the inefficient "agency costs" that managers supposedly extract from unwilling shareholders under the monitoring model is also likely to serve as a proxy for the efficient and legitimate benefits managers receive from mediating boards, with shareholders' ex ante blessing, under the mediating model. Put differently, the mediating model of the board suggests that when managers receive a greater share of corporate rents-whether in the form of high salaries, job security, or use of a corporate jet-this is not prima facie evidence of inefficiency any more than greater dividends paid to shareholders are evidence of inefficiency. Rather, both types of payments reflect effective team production under a mediating board.

Studies finding a correlation between director primacy rules and returns to nonshareholders accordingly provide just as much empirical support for the mediating model as they do for the monitoring model. It seems unlikely that these kinds of correlations can provide insight into whether IPO firms that adopt antitakeover provisions are harming or helping their shareholders in the process. ${ }^{91}$

${ }^{90}$ It also makes sense that antitakeover defenses are negatively correlated with CEO age, since a younger CEO who hopes to be around for some time has more to lose from ex post shareholder opportunism, and that antitakeover provisions are negatively correlated with executive stock ownership, as executives who retain enough stock to control the firm do not need antitakeover provisions to protect their specific investments because their voting rights accomplish this. See supra note 89.

${ }^{91}$ For a different problem that can occur in such studies, see Daines \& Klausner, supra note 74, at 95-113. In this study, the authors attempted to test whether antitakeover defenses were adopted to protect executives' "private benefits" (a phrase that incorporates the possibility that executives rely on mediating boards to provide them with an extracontractual share of the firm's surplus, as predicted by the mediating model). Daines and Klausner assumed that the magnitude of private benefits increased when the firm's founder was still CEO at the IPO stage. Id. They found a negative correlation between the presence of antitakeover defenses and a founder CEO, and concluded that a desire to protect executive private benefits could not explain the use of defenses. Id. Founder CEOs, however, are likely to be older than non-founder CEOs. See Field \& Karpoff, supra note 74, at 1859 (noting that the average age of firms "going public" is eighteen years, implying that founders who are still CEOs at the IPO stage have been at the helm for nearly two decades). Thus, a founder CEO may in fact have less to lose from a takeover than a younger CEO brought in to replace the founder. Daines and Klausner's results accordingly can be read to support the mediating board hypothesis that IPO firms use takeover defenses to efficiently protect the interests of executives who make specific investments that cannot be protected by formal contracts. 
How then might one go about investigating whether antitakeover defenses and other director primacy rules adopted at the IPO stage inefficiently harm investors, as supporters of the monitoring model have claimed? A second element of the Field and Karpoff study suggests a strategy that deserves further investigation. This strategy would not rely on shareholders' ex post (and possibly opportunistic) behavior as a means of gauging efficiency, nor would it look for correlations between antitakeover defenses and nonshareholder benefits and assume that anything benefiting nonshareholders must have come at the shareholders' expense. Instead, it would examine how antitakeover defenses affect firm value directly by examining how the adoption of such defenses at the IPO stage influences subsequent firm performance.

Consider how, under ideal circumstances, such a study might be structured. First, one would pull together a sample of firms on the verge of going public that elected to include antitakeover defenses in their charters. (The promoters of these firms presumably believe that antitakeover defenses increase net firm value.) Then, one would divide the sample into two subgroups: the first one would be instructed to eliminate antitakeover provisions from their charters, while the second (the control group) would be permitted to retain them. Then one would make a longitudinal study of the operating and stock-price performance of each group over some significant period of time-say, ten years. If the firms that were allowed to keep their antitakeover provisions performed better on average, one could conclude that director primacy does indeed increase firm value. Conversely, if these firms did worse, one could conclude, in accord with the monitoring model, that antitakeover defenses are inefficient.

As a practical matter, of course, such a study is impossible. Researchers cannot dictate to corporate promoters what antitakeover provisions they may or may not put in their charters. ${ }^{92}$ Nevertheless, Field and Karpoff attempted the next best thing, examining how the presence of antitakeover defenses at the IPO stage is related to the

92 As an altemative, experimenters might try to offer some valuable inducement in order to change promoters' behavior. This approach raises other difficulties, however: even if the experimenter could convince a foundation to fund a grant large enough to bribe a test group of firms into changing their charters, the problem of selfselection remains, as well as the issue of controlling for the wealth advantages enjoyed by firms accepting the bribes. 
subsequent operating performance of those firms in the following five years. $^{93}$

Their results offer an important challenge to the monitoring model. As Field and Karpoff observed, the agency cost explanation for antitakeover defenses, which relies on the monitoring model, implies that takeover defenses that insulate the firm's executives and directors from the corporate control market should weaken subsequent overall firm performance by encouraging inefficient shirking and stealing. ${ }^{94}$ The agency cost explanation accordingly predicts that IPO firms with antitakeover defenses should experience poor subsequent operating results compared to similar firms without defenses. ${ }^{95}$

Field and Karpoff, however, observed the opposite result: the postIPO performance of firms with takeover defenses tended to be better than the performance of firms without such defenses, especially in the first three years following the IPO.$^{96}$ As Field and Karpoff duly noted, this result was "inconsistent with the notion that takeover defenses at the time of the IPO contribute to poor operating performance. ${ }^{97}$ It is consistent, however, with the mediating model. ${ }^{98}$

The mediating model posits that, by adopting antitakeover provisions, IPO firms may offer additional assurance to executives, employees, and other stakeholders that they can make sunk-cost

${ }^{99}$ Field \& Karpoff, supra note 74, at 1881-83. Operating performance was measured by the firm's operating return on assets compared to a control firm with similar characteristics but no defenses. Id.

${ }^{94} I d$. at 1857.

${ }^{95} I d$. at 1881 . Implicit in this prediction is the assumption that antitakeover defenses cannot provide offsetting benefits, such as encouraging nonshareholders' specific investments, that improve subsequent firm performance.

${ }^{96}$ Id. at $1881-83$.

${ }^{97}$ Id. at 1883 .

${ }^{98}$ Such results are especially striking because attempts to measure how antitakeover defenses enhance firm value are likely to be plagued by false negatives due to selection bias. This is because antitakeover provisions likely increase the value of some firms (e.g., those most in need of stakeholders' extracontractual specific investments) more than others. Individual firms should adopt the governance structures (e.g., classified board or unclassified board) optimal for that firm. A corollary is that we may not see any subsequent performance difference between firms with and without antitakeover defenses because firms that decline to adopt such defenses should not suffer any relative disadvantage. Field and Karpoff's finding that IPO-stage defenses are associated with better operating performance accordingly provides even stronger evidence in support of the mediating model than appears on first inspection. It also suggests that, for some reason, firms that could benefit from the adoption of antitakeover defenses are not doing so. For a potential explanation, see Coates, supra note 73, at 1336 (arguing that the adoption of antitakeover defenses is determined in part by whether an IPO firm is advised by a high-quality law firm with experience in the field). 
commitments in relative safety. If this promise of security promotes investment in the firm, the result may be to improve the firm's subsequent operating results, especially in the years immediately following the IPO when the uncertainty surrounding any new venture makes it especially difficult to protect specific investments through formal contract. Thus, shareholders get exactly what they hope and expect to get by submitting to board governance-a flourishing public corporation. ${ }^{99}$

This is not to suggest that Field and Karpoff's test of operating results provides definitive proof of the superiority of the mediating model. Correlation is not causation, and there are competing explanations for why IPO antitakeover defenses might be associated with superior operating performance in a firm's early years. ${ }^{100}$ Nevertheless, while further empirical study of the effects of director primacy rules on firm value can be expected to run into such difficulties and uncertainties, the point is that further empirical work can, and should, be done. Until it is, corporate scholars cannot safely rely on even the normative version of the monitoring model of the board.

\section{CONCLUSION}

Contemporary corporate theorists face a quandary. For the past two decades, much of the scholarly literature on corporate governance has relied, explicitly or implicitly, on the monitoring model of the corporate board. The temptation to do this is understandablethe monitoring model offers an appealingly simple story about the nature of the firm, with shareholders as "principals" and directors as their "agents." This simple story can be easily explained to both laypeople and law students, including the students who manage most law reviews. Moreover, the monitoring model implies that one can measure "good" corporate governance according to the easily

${ }^{99}$ Similar support for the mediating model can be found in a recent study of firms that announced plans to create a second class of stock with limited voting rights. Such dual-class firms represent an extreme form of public shareholder disenfranchisement. Nevertheless, the study found that firms that adopted dual class structures enjoyed abnormally positive stock market and operating returns in the four years following the announcement. See generally Valentin Dimitrov \& Prem C. Jain, The Effect of Dual Class Recapitalization on Long-Run Stock Returns (Apr. 21, 2003) (unpublished manuscript, on file with author); Stout, supra note 25, at 855.

${ }^{100}$ In an informal discussion with the author, John Coates has suggested an alternative explanation for Field and Karpoff's results: high-quality law firms tend to advise their clients to use antitakeover provisions for reasons unrelated to efficiency, and better-performing firms tend to hire high-quality law firms. 
observed variable of share price. As a result, it allows researchers to argue that empirical studies of how changes in corporate law or structure influence share price provide persuasive evidence of what is good or bad for the corporate sector as a whole.

Nevertheless, several recent developments indicate that it is no longer wise (if it ever was) to assume that the monitoring model captures either the positive reality of how corporate boards work or the normative desideratum of how they should work. First, theoretical work in economics on the problem of contracting for specific investment in team production has breathed new intellectual life into the competing view of directors' roles as mediating hierarchs, rather than as shareholders' agents. Second, widespread use of the poison pill, especially when combined with corporations' increasing penchant for classified board structures, has highlighted how shareholders do indeed cede control over public firms to boards of directors, as predicted by the mediating model. Third, empirical inquiries into contemporary corporate governance patterns-especially recent studies of IPO charters-provide strong evidence that shareholders in public firms not only cede control to boards, but prefer to cede control to them.

Investors' revealed preference for director primacy rules at the IPO stage may possibly reflect imperfections in the IPO market rather than investors' true preferences. Yet the theoretical possibility that investors' revealed preferences might not reflect their true preferences does not establish that investors' revealed preferences do not reflect their true preferences. Before dismissing the strong and consistent results of IPO studies as irrelevant to the mediating versus monitoring board debate, it seems reasonable to demand some empirical counterweight, in the form of evidence that investors-despite their apparent enthusiasm for director primacy rules-in fact suffer from them over the life of the firm.

That counterweight remains missing. Meanwhile, casual observations of the empirical landscape-including the observations that (1) the default rules of corporate law favor director primacy; (2) public firms almost never opt out of these default rules; (3) public firms in fact increasingly add charter provisions to reinforce directors' authority; (4) charter provisions are added not only in seasoned firms, but also in IPOs; and (5) initial tests conclude that IPO antitakeover defenses actually improve firm performance, instead of harming it -all suggest that, at least for now, the mediating model enjoys the empirical high ground. 
The realities of modern corporate life accordingly strongly recommend that the monitoring model of the board lose the privileged status it has enjoyed during the past two decades, at least among academics. The monitoring versus mediating board debate has not, of course, been resolved. Nevertheless, it is time to move the debate away from assertion and speculation, and toward empirical work that can allow us to test each model's validity. In the interim, the burden of proof should be shifted to those who would defend the monitoring model. 